\title{
Konsep Adab Peserta Didik dalam Pembelajaran menurut Az-Zarnuji dan Implikasinya terhadap Pendidikan karakter di Indonesia
}

\author{
ALI NOER* \\ SYAHRAINI TAMBAK** \\ AZIN SARUMPAET $* * *$
}

\author{
*Fakultas Agama Islam (FAI) Universitas Islam Riau (UIR) Pekanbaru \\ Jl. Kaharuddin Nasution, No. 113, Perhentian Marpoyan Pekanbaru 28284 \\ **Fakultas Agama Islam (FAI) Universitas Islam Riau (UIR) Pekanbaru \\ Jl. Kaharuddin Nasution, No. 113, Perhentian Marpoyan Pekanbaru 28284 \\ e-mail: syahraini_tambak@yahoo.co.id \\ ***Fakultas Agama Islam (FAI) Universitas Islam Riau (UIR) Pekanbaru \\ Jl. Kaharuddin Nasution, No. 113, Perhentian Marpoyan Pekanbaru 28284
}

\begin{abstract}
Abstrak: Kepribadian seseorang tercermin dari akhlak yang mulia, dia akan mengantarkan seseorang kepada martabat yang tinggi. Akhir-akhir ini adab yang mulia merupakan hal yang mahal dan sulit dicari. Minimnya pemahaman akan nilai-nilai adab yang terkandung dalam al qur'an dan hadits akan semakin memperparah kondisi kepribadian seseorang. Untuk membentuk pribadi yang mulia, hendaknya penanaman adab terhadap anak digalakkan sejak dini, karena pembentukannya akan lebih mudah dibanding setelah anak tersebut menginjak dewasa. Al-jarnuzi membahas tentang beberapa konsep adab yang perlu kita aplikasikan dalam pembelajaran, sehingga akan tercipta pribadi yang santun sesuai tuntunan al qur" an. Jenis penelitian ini merupakan penelitian kajian pustaka. Untuk memperoleh data yang representatif dalam pembahasan skripsi ini digunakan metode penelitian kepustakaan (library research) dengan cara mencari mengumpulkan, membaca dan menganalisa buku-buku yang ada relevansinya dengan masalah penelitian, kemudian diolah sesuai dengan kemampuan penulis. Hasil temuan menunjukkan bahwa konsep adab dalam belajar yang di gagas oleh $\mathrm{Al}$ jarnuzi ini memiliki konsep adab belajar yang terklasifikasi ke dalam adab belajar murid terhadap Allah, adab belajar murid terhadap diri sendiri, adab belajar murid terhadap sesama (orang tua, guru, dan teman), dan adab belajar murid terhadap ilmu. Rekomendasi dalam penelitian ini, hendaknya semua pihak yang berkecimpung dalam pendidikan khususnya bagi seorang murid, harus senantiasa mengaplikasikan adab belajar yang telah digagas oleh Al-jarnuji ini ,agar memperoleh keberhasilan dan kesuksesan dalam belajar, sehingga mendapatkan ilmu yang bermanfaat.
\end{abstract}

Kata kunci : Adab Belajar, Al-Jarnuzi, Pendidikan Karakter

\section{PENDAHULUAN}

Adab merupakan bagian

pendidikan yang sangat penting yang berkenaan dengan aspek-aspek sikap

dan nilai, baik individu ataupun berhubungan dengan sosial masyarakat. Adab yang baik akan memberikan pengaruh dalam kehidupan. Sehingga ada pepatah yang mengatakan "adab lebih tinggi dari ilmu". Oleh karena itu 
nilai yang terkandung dalam agama perlu diketahui, dipahami, diyakini dan diamalkan oleh manusia Indonesia agar dapat menjadi dasar kepribadian sehingga dapat menjadi manusia yang utuh Mengingat begitu pentingnya adab dalam kehidupan, sampai hal terkecil pun mempunyai aturan tersendiri (Zainuddin Ali, 2011: 32-33).

Dalam mewujudkan perubahan dan perkembangan kearah yang lebih baik, maka perlu adanya penyesuaian dan realisasi dalam pembelajaran dan kehidupan, sehingga tujuan pendidikan tersebut dapat menghasilkan kualitas yang baik. Penyesuaian tersebut dapat dilakukan dengan kurikulum dan materi pembelajaran, proses pembelajaran dan pembinaan, serta dengan kegiatan ekstra kurikuler yang ada di lingkungan tersebut (H.M. Arifin, 2010: 135-136).

Fenomena-fenomena yang terjadi dalam dunia pendidikan saat ini, sebagai cermin tentang merosotnya adab siswa dalam pelaku pendidikan, baik dari segi pimpinan pendidikan, guru dan peserta didik. Kondisi tersebut akan berdampak terhadap kualitas pendidikan yang diharapkan. Salah satu contohnya adalah adab atau etika yang sudah semakin jauh atau hampir hilang dari setiap orang termasuk pada anak didik. Hal itu dapat dilihat dengan banyaknya siswa atau mahasiswa yang tidak mempunyai sopan santu dalam berbicara, berprilaku dan berpakaian yang tidak sesuai dengan konsep ajaran Islam, melanggar akhlak, peraturan sekolah kode etik ditingkat mahasiswa, itu semua menunjukkan bahwa kerusakan moral, akhlak dan adab sudah sangat memperihatinkan (Burhanuddin Salam, 2000: 3).

Maka hal terpenting bagi guru adalah menanamkan adab pada anak/siswa. Sebab anak merupakan amanah Allah yang harus dibina, dipelihara dan diurus secara seksama serta sempurna agar kelak berguna bagi agama, bangsa dan Negara dan secara khusus dapat menjadi pelipur lara orang tua, penenang hati ayah dan bunda serta sebagai kebanggaan (Abdullah Nasih Ulwan, 2002: VII).

Dalam sebuah pemberitaan disurat kabar yang diterbitkan oleh Indo pos pada edisi minggu 14 juni 2015, di beritakan sekumpulan pelajar aksi kompoi bersama di jalan raya dengan melakukan telanjang dan mencoretcoret baju sebagai bukti kegembiraan atas kelulusan yang diraih. Selain itu diberbagai wilayah Indonesia seperti di Kendal Usai Ujian Nasional Puluhan Pelajar Pesta Intim dalam merayakan kelulusannya (Indo pos, 14 juni 2015).

Sedangkan dalam penelitian Nurul (2012) dia menyebutkan bahwa dalam akhbar Berita Harian Online tanggal 04 agustus (2010), melaporkan bahwa dua orang pelajar tingkatan dua dari sebuah sekolah di Sarawak telah mengeluarkan kata-kata kotor terhadap gurunya dan telah memukul guru tersebut, pelajar tersebut didakwa menyerang dan memukul gurunya setelah dimarahi oleh guru tersebut. Selain dari itu, di dalam akhbar Berita Harian Online tanggal 12 Maret (2010), seorang wanita dipukuli sekumpulan enam pelajar perempuan kelas lima sebuah sekolah menengah di Petaling Jaya, wanita tersebut dibelasah di depan anaknya dan puluhan pelajar lain selepas memarahi seorang dari pada pelajar tersebut yang mengganggu serta mengejek anak perempuannya yang juga pelajar tingkatan lima sekolah tersebut.

Jika kenyataan seperti ini terus terjadi, sudah dapat dipastikan generasi yang akan datang akan jauh dari pada adab dan etika. Selain dari itu kompetensi lulusan yang diharapkan, yakni siswa yang mempunya adab dan unggul dalam bidang pengetahuan tidak akan tercapai dengan baik. Oleh karena itu, untuk memurnikan kembali kondisi yang sudah tidak relevan dengan nilai-

Jurnal Al-hikmah Vol. 14, No. 2, Oktober 2017 ISSN 1412-5382 
nilai Islam, satu-satunya upaya yang dapat dilakukan adalah dengan kembali kepada ajaran agama yang terdapat di dalamnya nilai-nilai akhlak mulia (Zakiah Darajad, 1987:182).

Sebagai bangsa yang lebih mengedepankan pendidikan dan moral yang sebagai kunci utama perkembangan dan kemajuan bangsa, maka pendidikan merupakan hal yang sangat penting. Hal tersebut tertuang dalam UUD 1945 dan tujuan pendidikan Nasional.

Mengingat begitu pentingnya pendidikan terhadap kemajuan bangsa dan agama, maka berbagai pemikiran muncul di kalangan pemikir dan tokoh pendidikan Islam baik di timur tengah dan Indonesia. Sebagai wujud tanggung jawab dan perhatian terhadap pendidikan dan moralitas serta akhlak generasi bangsa salah satunya adalah syaikh Al- Jarnuzi (Al-jumbulati \& Abdul futuh, 2002:v).

Dalam sejarah Islam terdapat seorang yang mempunyai kepedulian yang tinggi terhadap proses belajar, syaikh Az-Zarnuji, demikian namanya, menuangkan rangkaian pengalaman dan renungannya tentang bagaimana seseorang mestinya sukses belajar dalam sebuah kitab. Kitab tersebut diberi nama kitab Ta'limMuta'allim. Apa yang beliau tuliskan kemudian menjadi referensi dasar dari para santri (sebutan pelajar bagi siswa dilingkungan pondok pesantren) hingga saat ini. Terutama di pondok pesantren salaf.

Banyak para filosof muslim memberikan perhatian yang sanga besar lewat berbagai tulisanya terhadap eksistensi guru,termasuk didalamnya mengenai hak dan kewajibannya. Mereka banyak menulis tentang beberapa sifat yang harus dimiliki olehnya. Diantaranya adalah Burhanuddin Az-Zarnuji yang hidup sekitar akhir abad ke-12 danawal abad ke-13 M pada masa Bani Abbasiyah (Abuddin Nata, 2000:174).

Az-Zarnuji adalah sosok pemikir pendidikan Islam yang banyak menyoroti tentang etika dan dimensi spiritual dalam pendidikan Islam. Dalam karyanya Al- Zarnûjî lebih mengedepankan pendidikan tentang adab dalam proses pendidikan. Beliau mengisyaratkan pendidikan yang penekanannya pada mengolah hati sebagai asas sentral bagi pendidikan.

Az-Zarnuji dalam muqaddimah kitabnya"Ta'lîmal-Muta'allim"

menjelaskan latar belakang penyusunan kitabnya, yaitu diawali karena banyaknya para pencari ilmu yang tidak mendapat ilmu atau dia mendapat ilmu tapi tidak mendapat kemanfaatan dari ilmu tersebut. Itu disebabkan karena kurangnya akhlak atau adab dalam mencari ilmu. Kemerosotan moral para pencari ilmu dan pendidik yang dirasakan Az-Zarnuji pada saat itu, kini masih kita rasakan bahkan jauh lebih mengkhawtirkan.

Mengingat banyaknya masalah
diatas maka dalam melakukan
penelitian ini penulis memberikan batasan masalah, adapun yang di bahas hanya terkait konsep adab peserta didik dalam pembelajaran menurut Az-Zarnuji dan implikasi pemikiran Al-jarnuji tentang adab terhadap pendidikan karakter di Indonesia.

Mengingat pembatasan masalah di atas maka penulis merumusan masalah penelitian ini adalah : "Bagaimana konsep adab peserta didik dalam pembelajaran menurut Az-Zarnuji dan Bagaimana implikasi pemikiran AzZarnuji tentang adab terhadap pendidikan karakter di Indonesia."

Adapun tujuan penelitian ini yaitu: (1) Untuk mengetahui bagaimana konsep adab dalam pembelajaran menurut Az-Zarnuji; dan (2)Untuk mengetahui Implikasi pemikiran AzZarnuji tentang adab terhadap 
pendidikan karakter di Indonesia. Manfaat penelitian ini adalah: (1) Sebagai bahan referensi bagi pihak sekolah dan pendidik lainnya dalam mengembangkan konsep pendidikan Islam; (2) Sebagai salah satu sumbangan pemikiran bagi dunia akademis, praktis pendidikan, dan orang-orang yang bergelut dalam dunia pendidikan; dan (3) Untuk menumbuhkan kembali minat terhadap kajian-kajian tentang pemikiran pendidikan Islam, yang merupakan fenomena kebangkitan dunia Islam saat ini, untuk kemudian dapat menjadi referensi tambahan bagi pihak yang berkepentingan.

\section{KONSEP TEORI \\ Hakikat Adab}

Secara etimologis, adab adalah istilah bahasa arab yang artinya adat istiadat; ia menunjukkan suatu kebiasaan, etiket, pola perilaku yang ditiru dari orang-orang yang dianggap sebagai model. Kata adab (اداب) berasal dari kata دب artinya sesuatu yang bagus sekali, atau persiapan,pesta. "adab dalam pengertian ini sama dengan kata latin urbanitas, kesopanan, sopan santun, kehalusan budi bahasa dari orang-orang kota, kebalikan dari kekerasan orang badui. Jadi adab artinya akhlak yang baik (Ibrahim al-Kaysi, 2003:16). Adab juga bermakna pendidikan (Abd. Haris, 2010:63).

Secara terminologi adab adalah kebiasaan dan aturan tingkah laku praktis yang mempunyai muatan nilai baik yang diwariskan dari satu generasi ke generasi berikutnya (Abd. Haris, 2010:62). Menurut syed Muhammad AnNaquib Al-attas dalam Abd. Haris (2010) Adab adalah ilmu tentang tujuan mencari pengetahuan, Sedangkan tujuan mencari pengetahuan dalam Islam ialah menanamkan kebaikan dalam diri manusia sebagai manusia dan sebagai pribadi.

Jurnal Al-hikmah Vol. 14, No.
Demikian halnya menurut Marwan Ibrahim Al-Kaysi (2003) Adab adalah perilaku baik yang diambil dari Islam, berasal dari ajaran-ajaran dan perintahperintahnya. Senada dengan hal itu AlJurjani mengemukakan bahwa adab merupakan pengetahuan yang dapat menjauhkan seseorang yang beradab dari kesalahan-kesalahan. Adab adalah refleksi ideal-ideal mulia yang harus mengimpormasikan praktik keahlian (Abd. Haris, 2010:62).

Dari penjelasan diatas dapat kita simpulkan bahwa adab adalah kebiasaan dan aturan tingkah laku praktis yang mempunyai muatan nilai baik yang diambil dari Islam, berasal dari ajaran-ajaran dan perintahperintahnya, serta menanamkan kebaikan dalam diri manusia sebagai manusia dan sebagai pribadi.

\section{Konsep Implikasi}

Menurut Kamus Besar Bahasa Indonesia (KBBI) (2007:427) arti kata implikasi adalah keterlibatan atau keadaan terlibat. Sehingga setiap kata imbuhan dari implikasi seperti kata berimplikasi atau mengimplikasikan yaitu berarti mempunyai hubungan keterlibatkan atau melibatkan dengan suatu hal. Kata implikasi memiliki persamaan kata yang cukup beragam, diantaranya adalah keterkaitan, keterlibatan, efek, sangkutan, asosiasi, akibat, penerapan, konotasi, maksud, siratan, dan sugesti. Persamaan kata implikasi tersebut biasanya lebih umum digunakan dalam percakapan seharihari. Hal ini karena kata implikasi lebih umum atau cocok digunakan dalam konteks percakapan bahasa ilmiah dan penelitian.

\section{Hakikat Pendidikan Karakter}

Dalam kamus besar bahasa indonesia karakter adalah sifat-sifat 2, oktober 2017 ISSN 1412-5382 
kejiwaan, akhlak, atau budi pekerti yang membedakan seseorang dengan orang lain: tabiat dan watak (Elfindri \& Lilik Hendrajaya dkk, 2012:27). Menurut pusat bahasa depdiknas karakter adalah "bawaan, hati, jiwa, kepribadian, budi pekerti, perilaku, personalitas, sifat, tabiat, temperamen, watak". Adapun berkarakter adalah berkeperibadian, berperilaku, bersifat, bertabiat, dan berwatak (Zubaidi, 2013:8). Jika dilihat dari asal usul kata, banyak sekali pendapat mengenai dari mana kata karakter itu berasal. Ada yang berpendapat bahwa akar kata "karakter" ini, berasal dari kata dalam bahasa latin, yaitu "kharakter", "kharassein," dan "kharax," yang bermakna "tools for marking," "to engrave," dan "pointed stake." Kata ini konon mulai banyak digunakan dalam bahasa prancis sebagai "caractere" pada abad ke-14. Ketika masuk ke dalam bahasa inggris, kata "caractere" ini berubah menjadi "charcter." Ini mengalami perubahan menjadi "karakter"( Dani setiawan di dalam Agus wibowo,2013:8).

Pendapat lain menyebutkan bahwa istilah karakter berasal dari bahasa yunani yang berarti "to mark (menandai)," yaitu menandai tindakan atau tingkah laku seseorang. Kemudian istilah tersebut banyak digunakan dalam bahasa perancis "caratere" pada abad ke-14 dan kemudian masuk ke dalam bahasa inggris menjadi "character," yang akhirnya menjadi bahasa indonesia "karakter". Menurut American Dictionary of the English Language karakter merupakan istilah yang menunjukkan kepada aplikasi nilai-nilai kebaikan dalam bentuk tindakan atau tingkah laku. Karakter juga identik dengan keperibadian (Agus wibowo, 2013:8-9).

Demikian halnya menurut Suyanto karakter adalah cara berpikir dan perilaku yang menjadi ciri khas tiap individu untuk hidup dan bekerja sama, baik dalam lingkungan keluarga, masyarakat, bangsa dan negara. Senada dengan Suyoto Taryan dan Rinaldi mengemukakan bahwa karakter itu terbentuk dri proses meniru, yaitu melalui proses melihat, mendengar dan mengikuti. Maka karakter sesungguhnya dapat diajarkan secara sengaja (Wibowo \& Purnomo, 2013:36).

Secara ringkas, karakter menurut Ki Hadjar Dewantara adalah sebagai sifatnya jiwa manusia, mulai dari anganangan hingga terjelma menjadi tenaga. Dengan adanya budi pekerti, manusia akan menjadi pribadi yang merdeka sekaligus berkepribadian, dan dapat mengendalikan diri sendiri. Menurut Marzuki karakter identik dengan akhlak, sehingga karakter merupakan nilai-nilai perilaku manusia yang universal yang meliputi seluruh aktivitas manusia, baik dalam rangka berhubungan dengan tuhan, dengan diri sendiri, dengan sesama manusia, maupun dengan lingkungan, yang terwujud dalam pikiran, sikap, perasaan, perkataan, dan perbuatan berdasarkan norma-norma agama, hukum, tata karma, budaya, dan adat istiadat. Dan menurut kemendiknas karakter adalah watak, tabiat, akhlak, atau kepribadian seseorang yang terbentuk dari hasil internalisasi berbagai kebajikan (virtues), yang diyakini dan digunakan sebagai landasan untuk cara pandang, berpikir, bersikap, dan bertindak (Wibowo, 2013:10-11).

Menurut Lickona dalam Wibowo (2012:32) karakter adalah sifat alami seseorang dalam merespon situasi secara bermoral. Lebih lanjut lickona menekankan pentingnya tiga komponen karakter yang baik (components of good character), yaitu moral knowing atau pengetahuan tentang moral, moral feeling atau perasaan tentang moral dan moral action atau tindakan moral (E.Mulyasa, 2011:4). Senada dengan hal ini, menurut Griek dalam Adrianto 185 Jurnal Al-hikmah Vol. 14, No. 2, Oktober 2017 
(2011:17) bahwa karakter didefenisikan sebagai paduan dari pada segala tabiat manusia yang bersifat tetap sehingga menjadi tanda yang khusus untuk membedakan orang yang satu dengan yang lain. Sedangkan menurut Damanik mengutip tulisan Leonardo A. Sjiamsuri bahwa karakter merupakan gambaran siapa anda sesungguhnya.

Alwisol juga mengemukakan pendapat bahwa karakter adalah gambaran tingkah laku yang menonjolkan nilai benar-salah, baikburuk, baik secara eksplisit maupun implisit (Andrianto, 2011:20).

Demikian halnya menurut Suyanto karakter adalah cara berpikir dan perilaku yang menjadi ciri khas tiap individu untuk hidup dan bekerja sama, baik dalam lingkungan keluarga, masyarakat, bangsa dan negara. Senada dengan Suyoto Taryan dan Rinaldi mengemukakan bahwa karakter itu terbentuk dri proses meniru, yaitu melalui proses melihat, mendengar dan mengikuti. Maka karakter sesungguhnya dapat diajarkan secara sengaja(Wibowo \& Purnomo, 2013:36).

Menurut Simon Philips karakter adalah kumpulan tata nilai yang menuju pada suatu sistem, yang melandasi pemikiran, sikap, dan perilaku yang ditampilkan. Sementara itu Koesama A. Menyatakan bahwa karakter sama dengan keperibadian. Imam Al-ghozali menganggap bahwa karakter lebih dekat dengan akhlak, yaitu spontanitas manusia dalam bersikap, atau perbuatan yang telah menyatu dalam diri manusia sehingga ketika muncul tidak perlu dipikirkan lagi (Muslich, 2011:70).

Sedangkan pendidikan karakter secara harfiah dapat diartikan mengubah atau membentuk watak, perilaku, perangai, tabi'at dan kepribadian seseorang sesuai dengan kriteria yang ditentukan. Sedangkan secara esensial pendidikan karakter merupakan upaya untuk membantu perkembangan jiwa anak-anak baik lahir maupun batin, dari sifat kodratnya menuju kearah peradaban manusia yang lebih baik. Pendidikan karakter memiliki makna lebih tinggi dari pendidikan moral, karena pendidikan karakter tidak hanya berkaitan dengan masalah benarsalah, tetapi bagaimana menanamkan kebiasaan (habit) tentang hal-hal yang baik dalam kehidupan, sehingga anak/ peserta memiliki kesadaran, dan pemahaman yang tinggi, serta kepedulian dan komitmen untuk menerapkan kebajikan dalam kehidupan sehari-hari (E.Mulyasa, 2011:3).

Pendidikan karakter secara sederhana dapat diartikan membentuk tabiat, perangai, watak, dan kepribadian seseorang dengan cara menanamkan nilai-nilai luhur, sehingga nilai-nilai tersebut mendarah daging, menyatu dalam hati, pikiran, ucapan dan perbuatan, dan metampakkan pengaruhnya dalam realitas kehidupan secara mudah, atas kemauan sendir, orisinal, dan karena ikhlas semata karena Allah SWT (Abuddin Nata,2013:288).

Raharjo memaknai pendidikan karakter sebagai suatu proses pendidikan secara holistis yang menghubungkan dimensi moral dengan ranah sosial dalam kehidupan peserta didik sebagai pondasi bagi terbentuknya generasi yang berkualiatas yang mampu hidup mandiri dan memiliki prinsip suatu kebenaran yang dapat dipertanggung jawabkan. Demikian halnya menurut Creasy mengartikan pendidikan karakter sebagai upaya mendorong peserta didik tumbuh dan berkembang dengan kompetensi berpikir dan berpegang teguh pada prinsip-prinsip moral dalam hidupnya serta mempunyai keberanian melakukan yang benar, meskipun dihadapkan pada berbagai tantangan. Menurut Dony kusuma, pendidikan karakter merupakan dinamika

Jurnal Al-hikmah Vol. 14, No. 2, Oktober 2017 ISSN $1412-5382$ 
pengembangan kemampuan yang berkesinambungan dalam diri manusia untuk mengadakan internalisasi nilainilai sehingga menghasilkan disposisi aktif, stabil dalam diri individu (Zubaidi, 2013:16-19).

Menurut E.Mulyasa (2011:7) pendidikan karakter merupakan suatu sistem penanaman nilai-nilai karakter kepada pserta didik yang meliputi komponen: kesadaran, pemahaman, kepedulian, dan komitmen yang tinggi untuk melaksanakan nilai-nilai tersebut, baik terhadap Allah Tuhan Yang Maha Esa, diri sendiri, sesama, lingkungan, maupun masyarakat dan bangsa secara keseluruhan, sehingga menjadi manusia sempurna sesuai dengan kodratnya. Demikian halnya menurut Suyanto karakter adalah cara berpikir dan perilaku yang menjadi ciri khas tiap individuuntuk hidup dan bekerja sama, baik dalam lingkungan keluarga, masyarakat, bangsa dan negara. Senada dengan Suyoto Taryan dan Rinaldi mengemukakan bahwa karakter itu terbentuk dri proses meniru, yaitu melalui proses melihat, mendengar dan mengikuti. Maka karakter sesungguhnya dapat diajarkan secara sengaja (Wibowo \& Purnomo, 2013:36).

Secara akademis pendidikan karakter dimaknai sebagai pendidikan nilai, pendidikan budi pekerti, pendidikan moral, pendidikan watak, atau pendidikan akhlak yang tujuannya mengembangkan kemampuan peserta didik untuk memberikan keputusan baik-buruk, memelihara apa yang baik itu, dan mewujudkan kebaikan itu dalam kehidupan sehari-haridengen sepenuh hati. Secara praktis, pendidikan karakter adalah suatu sistem penanaman nilainilai kebaikan kepada warga sekolah atau kampus yang meliputi komponen pengetahuan, kesadaran atau kemauan, dan tindakan untuk melaksanakan nilai tersebut.

\section{Adab Peserta Didik Dalam Pembelajaran}

Bagi para pelajar, adab yang harus di amallkannya dalam menuntut ilmu menrut Imam Al-Ghazali, yaitu: Pertama, mendahulukan kebersihan jiwa dari akhlak yang rendah. Berdasarkan hadits Rasulullah SAW "agama didirikan diatas kebersihan". Bukan yang dimaksud kebersihan pakaian, tetapi kebersihan hati. Hal ini di tujukan dalam firman Allah:

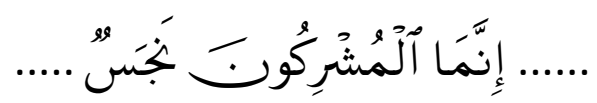

\section{Artinya: "Sesungguhnya orang-orang musyrik itu najis (Q.S. At- Taubah:28).}

Maka selama batin tidak dibersihkan dari hal-hal keji, ia pun tidak menerima ilmu yang bermamfaat dalam agama dan tidak diterangi dengan cahaya ilmu. Ibnu mas'ud berkata: "bukanlah ilmu itu karena benyak meriwayatkan, tetapi ilmu itu adalah cahaya yang dimasukkan ke dalam hati".

Kedua, mengurangi kesenangan kesenangan duniawi dan menjauh dari kampung halaman hingga hatinnya terpusat untuk ilmu. Allah tidak menjadikan dua hati bagi seseorang di dalam rongga badannya. Oleh karena itu dikatakan, "ilmu itu tidak memberikan sebagiannya hingga engkau memberikan seluruh milikmu".

Ketiga, tidak sombong dan tidak membangkang kepada guru, tetapi memberikannya kebebasan. Seperti orang yang gawat memberikan kebebasan kepada dokter tanpa berbuat sewenang-wenang terhadapnya dengan sesuatu dalam menuntut suatu macam obat tertentu. Maka sepatutnyalah ia berkhidmat kepada guru. Dikatakan bahwa ilmu itu enggan kepada orang yang sombong seperti air yang enggan mengalir ketempat yang tinggi. 
Keempat, menghindar dari mendengarkan perselisihanperselisihan diantara manusia, karna hal ini menimbulkan kebingungan.

Kelima, tidak menolak suatu bidang ilmu yang terpuji, tetapi ia menekuninya hingga mengetahui maksudnya. Jika umur membantunya, ia pun menyempurnakannya. Kalau tidak, ia memilih yang paling penting.

Keenam, mengalihkan perhatian kepada ilmu yang terpenting, yaitu ilmu akhirat. Saya maksudkan dengan itu adalah bagian muamalat dan mukasyafah. Muamalat dapat mendorong kepada mukasyafah sedangkan mukasyafah adalah makrifatullah (mengenal Allah). Itu adalah cahaya yang dimasukkan Allah di dalam hati yang bersih dengan ibadah dan mujahadah. Ketahuilah bahwa ilmu yang paling mulia dan puncaknya adalah mengenal Allah. Ini adalah lautan yang yang tidak terjangkau dasarnya.

Ketujuh, hendaknya tujuan pelajar dalam masa sekarang ialah menghiasi batinnya dengan sifat yang menyampaikannya kepada allah dan kepada derajat tertinggi diantara para malaikat muqarrabin (yang dekat dengan Allah). Dan dengan ilmu itu ia tidak mengharapkan kepemimpinan, harta, dan pangkat (Al-Ghazali,2007:1114).

\section{Pentingnya Adab Dalam Pembelajaran}

Banyak sekali riwayat dan penukilan yang menjelaskan tentang pentingnya mempunyai adab. Habib alJalab berkata :" aku bertanya kapada Ibnul mubarak: "apakah sebaik-baik perkara yang diberikan kepada seseorang ? dia menjawab: "adab yang baik". Imam asy-syafii juga mengatakan bahwa :" barang siapa yang ingin Allah membukakan hatinnya atau meneranginnya, hendaklah ia ber- khalwat (menyendidir), sedikit makan, meninggalkan pergaulan denga orangorang bodoh dan membenci ahli ilmu yang tidak memiliki inshaf (sikap objektif) dan adab.

Ibnu sirin berkata :"para salaf mempelajari adab sebagaimana mempelajari ilmu. Demikian halnya menurut Al-hasan bahwa sesungguhnya seorang laki-laki keluar untuk menuntut ilmu adab baginya selama dua tahun, kemudian dua tahun. Senada dengan hal itu Habib bin Asy-Syahid berkata kepada anaknya: "wahai anakku, pergaulilah para fuqaha dan ulama; belajarlah dan ambil adab dari mereka. Sesungguhnya hal itu lebih aku sukai dari pada banyak hadits.

Ibnul mubarak berkata: "aku mempelajari adab selama tiga puluh tahun dan aku mempelajari ilmu selama dua puluh tahun. Adalah para ulama dulu mempelajari adab baru mempelajari ilmu. Al-Qarafi juga berkata dalam kitabnya, Al-faruq, ketika menjelaskan kedudukan adab: “ ketahuilah bahwa sanya sedikit adab lebih baik dari pada banyak amal. Oleh karna itu, Ruwaiyim seorang alim yang saleh berkata kepada anaknya: "wahai anakku, jadikanlah amalmu ibarat garam dan adabmu ibarat tepung. Yaitu perbanyaklah adab sehingga perbandingan banyaknya seperti perbandingan tepung dan garam dalam suatu adonan. Banyak adab dengan sedikit amal saleh lebih baik dari pada amal dengan sedikit adab (As-sayyid Nada,2007:11).

\section{Pendidikan Karakter Dalam Pembelajaran \\ Tujuan dan manfaat pendidikan karakter}

Pendidikan karakter bertujuan untuk meningkatkan mutu proses dan hasil pendidikan mengarah pada pembentukan karakter dan akhlak mulia 2, Oktober 2017 ISSN 1412-5382 
peserta didik secara utuh, terpadu, dan seimbang, sesuai dengan standar kompetensi lulusan pada setiap satuan pendidikan. Melalui pendidikan karakter peserta didik diharapkan mampu secara mandiri meningkatkan dan menggunakan pengetahuannya, mengkaji dan menginternalisasikan serta mempersonalisasikan nilai-nilai karakter dan akhlak mulia sehingga terwujud dalam perilaku sehari-hari.

Pendikan karakter pada tingkat satuan pendidikan mengarah pada pembentukan budaya sekolah/madrasah, yaitu nilai-nilai yang melandari perilaku, tradisi, kebiasaan sehari-hari, serta simbol-simbol yang dipraktikkan oleh semua warga sekolah/madrasah, dan masyarakat sekitarnya. Budaya sekolah/madrasah merupakan ciri khas, karakter atau watak, dan citra sekolah/madrasah tersebut dimata masyarakat luas (E. Mulyas, 2011:9).

Senada dengan hal ini Socrates berpendapat bahwa tujuan paling mendasar dari pendidikan karakter adalah untuk membuat seseorang menjadi good and smart. Dalam sejarah Islam, Rasulullah Saw, juga menegaskan bahwa misi utamanya dalam mendidik manusia adalah untuk mengupayakan pembentukan karakter yang baik (good character). Berikutnya, ribuan tahun setelah itu, rumusan tujuan utama pendidikan tetap pada wilayah serupa, yakni pembentukan kepribadian manusia yang baik.tokoh pendidikan barat yang mendunia seperti Klipatrick, Lickona, Brooks dan Goble seakan menggemakan kembali gaung yang disuarakan oleh Muhammad Saw dan Socrates. Bahwa moral, akhlak, atau karakter adalah tujuan yang tak terhindar dari dunia pendidikan.

Demikian halnya pakar pendidikan Indonesia, Fuad Hasan, dengan tesis pendidikan yakni pembudayaan, juga ingin menyampaikan hal yang sama 189 Jurnal Al-hikmah dengan tokoh- tokoh pendidikan di atas. Menurutnya, pendidikan bermuara pada pengalihan nilai-nilai budaya dan norma-norma sosial (transmission of cultural values and social norms). Sementara Mardiatmaja menyebut pendidikan karakter sebagai ruh pendidikan dalam memanusiakan manusia (Majid \& Andayani, 2011:30).

\section{Pembentukan karakter dalam pembelajaran}

Untuk menyukseskan pendidikan karakter di sekolah-sekolah, perlu dilakukan indentifikasi karakter, karena pendidikan karakter tanpa indentifikasi karakter hanya akan menjadi sebuah perjalanan panjang tanpa ujung, seperti petualangan tanpa peta (E.Mulyasa, 2011:15).

Maka dalam hal ini, agar pendidikan karakter disekolah dapat berhasil, maka syarat utama yang harus dipenuhi, diantaranya: (1) teladan dari guru, karyawan, pimpinan sekolah, dan para pemangku kebijakan disekolah; (2) pendidikan karakter dilakukakan secara konsisten dan secara terus menerus; dan (3) penanaman nilai-nilai karakter yang utama. Karena semua guru adalah pendidik, maka mereka mamiliki kewajiban untuk memasukkan atau menyilipkan nilai-nilai pendidikan karakter dalam kegiatan pembelajaran (intervensi). Pendek kata, pendidikan karakter itu tidak hanya menjadi tugas guru agam, guru pkn, atau guru-guru yang mengajar moral; tetapi menjadi kewajiban semua guru disekolah. Hal ini penting agar ditengah prose pendidikan karakter tidak terjadi saling lempar tanggung jawab (Wibowo, 2012:45).

Upaya untuk mengimpelemtasikan pendidikan karakter perlu dilakukan dengan pendekatan holistik, yaitu mengintegrasikan perkembangan karakter ke dalam setiap aspek kehidupan sekolah (Zubaidi, 2013:195). 
Implementasi pendidikan karakter bisa dilakukan melalui: (a) Terintegrasi dalam pembelajaran, artinya pngenalan nilai-nilai, kesadaran akan pentingnya nilai-nilai, dan penginternalisasikan nilai-nilai ke dalam tingkah laku peserta didik melalui proses pembelajaran; baik yang berlangsung di dalam maupun diluar kelas pada semua mata pelajaran; (b) Terintegrasi dalam pengembangan diri melalui kegiatan ekstrakulikuler, artinya berbagai hal terkait dengan karakter diimplementasikan dalam kegiatan pengembangan diri melalui ekstrakulikuler yang memuat pembentukan karakter antara lain: olah raga, keagamaan, seni budaya, kepramukaan, palang merah remaja, pameran lokakarya, dan lain-lain; dan (c) Terintegrasi dalam manajemen sekolah, artinya berbagai hal terkait dengan karakter (nilai-nilai, norma, iman, dan ketaqwaan, dan lain-lain) dirancang dan diimplementasikan dalam aktivitas manajemen sekolah, seperti pengelolaan: peserta didik, regulasi/peraturan sekolah, sumber daya manusia, sarana dan prasarana, keungangan, perpustakaan, pembelajaran, penilaian, dan informasi serta pengelolaan lainnya.

Pendidikan karakter dapat diintegrasikan dalam pembelajaran pada setiap mata pelajaran. Materi pembelajaran yang berkaitan dengan norma atau nilai-nilai pada setiap mata pelajaran perlu dikembangkan, dieksplisitkan, dikaitkan dengan konteks kehidupan sehari-hari (Muslich, 2011:86).

\section{Ruang lingkup pendidikan karakter}

Disadari bahwa karakter/akhlak/ moral yang dimiliki manusia bersifat fleksibel atau luwes serta bisa diubah atau dibentuk. Karakter/akhlak/moral manusia suatu saat bisa baik tetapi pada saat yang lain sebaliknya menjadi jahat.
Perubahan ini tergantung bagaimana proses interaksi antara potensi dan sifat alami yang dimiliki manusia dengan kondisi lingkungannya, sosial budaya, pendidikan dan alam (Zubaidi, 2013:71). Allah SWT berfirman :

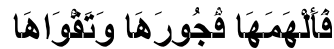

Artinya: "Maka Allah mengilhamkan kepada jiwa itu (jalan) kefasikan dan ketakwaannya." (Q.S. Asy-syam).

Oleh sebab itu para ahli mengatatakan bahwa Karakter dapat dibagi menjadi empat, yaitu: (a) Karakter lemah, dapat ditemukan seperti penakut, tidak berani mengambil resiko, pemalas, cepat kalah, dan beberapa jenis lainnya; (b) Karakter kuat, dapat ditemukan seperi tangguh, ulet, mempunyai daya juang yang kuat serta pantang menyerah/mengalah; (c) Karakter jelek, misalnya licik, egois, serakah, sombong, tinggi hati, snoobish, pamer, atau suka ambil muka, dan sebagainya; dan (d) Karakter baik, misalnya jujur, terpercaya, rendah hati, amanah dan sebagainya (Elfindri, Hendrajaya, Dkk, 2012:27-28).

Secara ringkas ajaran ajaran mulia pembentukan karakter dari berbagai suku bangsa yang ada di negri ini, diantaranya: reflektif, percaya diri, rasional, logis, kritis, analitis, kreatif dan inovatif, mandiri, hidup sehat, bertanggung jawab, cinta ilmu, sabar, berhati-hati, rela berkorban, pemberani, dapat dipercaya, jujur, menepati janji, adil, rendah hati, malu berbuat salah, pemaaf, barhati lembut, setia, bekerja keras, tekun, ulet/gigih, teliti, berinisiatif, berpikir positif, disiplin, antisipatif, inisiatif, visioner, bersahaja, bersemangat, dinamis, hemat, menghargai waktu, pengabdian/ dedikatif, penegndalian diri, produktif, ramah, cinta keindahan, sportif, tabah, terbuka, tertib, memiliki kesadaran untuk memperbuat yang terbaikatau unggul, mampu bertindak sesuai potensi 2, Oktober 2017 ISSN 1412-5382 
dan kesadaran tersebut, melakukan halhal terbaik terhadap tuhan YME, dirinya, sesama, lingkungan, bangsa dan negara serta dunia internasional pada umumnya dengan mengoptimalkan potensi (pengetahuan) dirinya dan disertai dengan kesadaran, emosi dan motivasinya (Wibowo, 2012:42).

Oleh karena itu, pendidikan karakter pada dasarnya adalah pengembangan nilai-nilai yang berasal dari pandangan hidup atau idiologi bangsa indonesia, agama, budaya, dan nilai-nilai yang terumuskan dalam tujuan pendidikan nasional. Nilai-nilai yang dikembangkan dalam pendidikan karakter di indonesia diidentifikasi berasal dari empat sumber.

Pertama, agama. Masyarakat indonesia merupakan masyarakat yang beragama. Oleh karena itu, kehidupan individu, masyarakat, dan bangsa selalu didasari pada ajaran agama dan kepercayaannya.

Kedua, pancasila. Negara kesatuan Republik Indonesia ditegakkan atas prinsip-prinsip kehidupan kebangsaan dan kenegaraan yang disebut pancasila. Pancasila terdapat pada pembukaan UUD 1945 yang dijabarkan lebih lanjut ke dalam pasal-pasal yang terdapat dalam UUD 1945. Artinya nilai-nilai yang terkandung dalam pancasila menjadi nilai-nilai yang mengatur kehidupan politik, hukum, ekonomi, kemasyarakatan, budaya, dan seni.

Ketiga, budaya. Sebagai suatu kebenaran bahwa tidak ada manusia yang hidup bermasyarakat yang tidak didasari nilai-nilai budaya yang di akui masyarakat tersebut. Posisi budaya yang demikian penting dalam kehidupan masyarakat mengharuskan budaya menjadi sumber nilai dalam pendidikan budaya dan karakter bangsa.

Keempat, tujuan pendidikan nasional. Undang-Undang Republik Indonesia Nomor 20 tahun 2003 tentang sistem pendidikan nasional (UU 191 Jurnal Al-hikmah Vol. 14, No. 2, Oktober 2017

sisdiknas) merumuskan fungsi dan tujuan pendidikan nasional yang harus digunakan dalam mengembangkan upaya pendidikan di Indonesia.

\section{Pendidik karakter di Indonesia}

Berdasarkan Undang-Undang Republik Indonesia Nomor 20 tahun 2003 tentang sistem pendidikan nasional (UU sisdiknas) teridentifikasi sejumlah nilai untuk pendidikan karakter yaitu: (1) Religius yaitu: sikap dan perilaku yang patuh dalam melaksanakan ajaran agama yang dianutnya, toleran terhadap pelaksana ibadah agama lain, dan hidup rukun dengan pemeluk agama lain; (2) Jujur yaitu: perilaku yang didasarkan pada upaya menjadikan dirinya sebagai orang yang selalu dapat dipercaya dalam perkataan, tindakan, dan pekerjaan; (3) Toleransi yaitu: Sikap dan tindakan yang meghargai perbedaan agama, suku, etnis, pendapat, sikap, dan tindakan orang lain yang berbeda dari dirinya; (4) Disiplin yaitu: tindakan yang menunjukkan perilaku tertib dan patuh pada berbagai ketentuan dan peraturan; (5) Kerja keras yaitu: perilaku yang menunjukkan upaya sungguh-sungguh dalam mengatasi berbagai hambatan belajar dan tugas, serta menyelesaikan tugas dengan sebaik-baiknya; (6) Kreatif yaitu: perpikir dan melakukan sesutau untuk menghasilkan cara atau hasil baru dari sesuatu yang telah dimiliki; (7) Mandiri yaitu: sikap dan perilaku yang tidak mudah tergantung pada orang lain dalam menyelesaikan tugas-tugas; (8) Demokratis yaitu: cara berpikir, bersikap, dan bertindak yang menilai sama hak dan kewajiban dirinya dan orang lain; (9) Rasa ingin tahu yaitu: sikap dan tindakan yang selalu berupaya untuk mengetahui lebih mendalam dan meluas dari sesuatu yang dipelajarinya, dilihat, dan didengar; (10) Semangat kebangsaan yaitu: cara berpikir, ISSN 1412-5382 
bertindak, dan berwawasan yang menempatkan kepentingan bangsa dan negara di atas kepentingan diri dan kelompoknya; (11) Cinta tanah air yaitu: cara berpikir, bersikap, dan berbuat yang menunjukkan kesetiaan, kepedulian, dan penghargaan yang tinggi terhadap bahasa, limgkungan fisik, sosial, budaya, ekonomi, dan politik bangsa; (12) Menghargai perestasi yaitu: sikap dan tindakan yang mendorong dirinya untuk menghasilkan sesuatu yang berguna bagi masyarakat, dan mengakui, serta menghormati keberhasilan orang lain;

Bersahabat/ komunikatif yaitu: tindakan yang memperlihatkan rasa senang berbicara, bergaul, dan bekerja sama dengan orang lain; (14) Cinta damai yaitu: sikap, perkataan, dan tindakan yang menyebabkan orang lain merasa senang dan aman atas kehadiran dirinya; (15) Gemar membaca yaitu: kebiasaan menyediaakan waktu untuk membaca berbagai bacaan yang memberikan kebajikan bagi dirinya; (16) Peduli lingkungan yaitu: sikap dan tindakan yang selalu berupaya mencegah kerusakan pada lingkungan alam sekitarnya, dan mengembangkan upaya-upaya untuk memperbaiki kerusakan alam yang sudah terjadi; (17) Peduli sosial yaitu: sikap dan tindakan yang selalu ingin memberi bantuan pada orang lain dan masyarakat yang membutuhkan; dan (18) Tanggung jawab yaitu: Sikap dan perilaku seseorang untuk melaksanakan tugas dan kewajibannya, yang seharusnya dilakukan terhadap diri sendiri, masyarakat, lingkungan, (alam, sosial, dan budaya), negara, dan tuhan yang maha esa (Wibowo, 2013:26-27).

Idealnya, pendidikan karakter yang baik itu adalah sejak di usia dini (PAUD), sekolah taman kanak-kanak (TK), pendidikan dasar dan menengah, hingga pendidikan di perguruan tinggi (Wibowo, 2013:29). Hal senada juga diungkapkan oleh Leonardy Harmain (dalam wibowo,2012) pendidikan karakter itu sebaiknya dimulai sejak anak dalam fase usia dini, khususnya dilingkungan keluarga. Bukan hanya karena keluarga merupakan lingkungan yang efektif, tetapi juga karena usia kanak-kanak merupakan usia keemasan atau sering disebut ahli psikologi sebagai golden ege. Usia ini, lanjut Leonardy, terbukti sangat menentukan kemampuan anak dalam mengembangkan potensinya.

Konsep opersional adalah konsep yang digunakan untuk menjabarkan atau memberi batasan terhadap konsep teoritis. karakter adalah pendidikan yang menanamkan dan mengembangkan karakter-karakter luhur sehingga dapat di terapkan dan di aplikasikan dalam kehidupan, entah dalam keluarga, sebagai anggota masyarakat dan warga negara. Dengan demikian, pendidikan karakter adalah segala upaya yang dilakukan guru yang mampu mempengaruhi serta membantu membentuk watak peserta didik. Oleh sebab itu perlu suatu konsep operasional atau parameter, sebagai dasar berpijak, yaitu: (1) Niat saat belajar; (2) Memilih ilmu, guru, dan teman; (3) Menghormati ilmu dan ahli ilmu; (4) Keseriusan, ketekunan dan cita-cita luhur; (5) Metode belajar; (6) tawakkal; dan (7) wara'.

\section{METODE}

Penelitian ini termasuk jenis penelitian kepustakaan (library research) yaitu serangkaian penelitian yang berkenaan dengan metode pengumpulan data pustaka atau penelitian yang dilakukan di perpustakaan yang obyek penelitian biasanya digali lewat beragam informasi kepustakaan (buku, ensiklopedi, jurnal ilmiah, koran, majalah, dan dokumen) (Nana Syaodih Sukmadinata, 2009: 52). 
Penelitian ini dilakukan selama empat bulan, terhitung dari pembuatan proposal sampai dengan ujian sarjana, empat bulan yakni dari bulan JuliOktober 2016. Dalam penelitian ini penulis memperoleh data dari berbagai sumber. Kemudian data tersebut diklasifikasikan menjadi data primer dan data sekunder. Sumber primer adalah semua bahan-bahan informasi dari tangan pertama atau dari sumber orang yang diperolah dari data asli atau pokok (Mestika Zed, 2004: 89) Diantanya yaitu: تعليم المتعلم (Ta'limul mutaa'llim), penulis syekh az-zarnuji. Sedangkan data Sekunder merupakan sumber data bersifat umum untuk meneliti yang isinya mendukung data primer yaitu data-data yang berkaitan judulpenelitian yang peneliti lakukan baik berupa buku-buku, hasil penelitian, jurnal, dan literatur lainnya, diantaranya sebagai berikut: (1) Al-Amir Najib Khalid, Tarbiyah Rasulullah, Jakarta: Gema Insani Press, 1995;(2) Mahmud Yunus, Sejarah Pendidikan Islam, Jakarta: Mahmud Yunus Wadzurriyah, 2008; (3) Ramayulis \& Samsul Nizar, Eknsiklopedi Tokoh Pendidikan Islam, Mengenal Tokoh Pendidikan di Indonesia dan Islam, Ciputat: Quantum Teaching, 2005; dan (4) Abuddin Nata, Pemikiran Para Tokoh Pendidikan Islam, Jakarta: Raja Grafindo, 2000.

Dalam pengolahan analisa data dengan menggunakan langkah-langkah, yaitu:(1) Data reduction (reduksi data);

(2) Data display (penyajian data); dan

(3) Conclusion drawing/verification.

\section{HASIL DAN PEMBAHASAN Biografi Al-Jarnuzi}

Kata Syaikh adalah panggilan kehormatan untuk pengarang kitab Ta'lim Al-Muta'allim ini. Sedang AzZarnuji adalah nama marga yang diambil dari nama kota tempat beliau berada, yaitu kota Zarnuj. Di antara dua kata itu ada yang menuliskan gelar Burhanuddin (bukti kebenaran agama), sehinnga menjadi Syaikh Burhanuddin Az-Zarnuji.

Namun demikian nama ini masih diperdebatkan kebenarannya, karena masih belum ditemukan data yang valid mengenai nama asli Az-Zarnûjî. Khairuddin al-Zarkeli menuliskan nama Az- Zarnûjî dengan an-Nu'mân bin Ibrâhim bin Khalîl az-Zarnûjî Tajuddin. Nama akhirnya dinisbahkan dari daerah tempat dia berasal, yakni Zarnûj, yang akhirnya melekat sebagai nama panggilan. Plessner, dalam The Encyclopedia of Islam mengatakan bahwa nama asli tokoh ini sampai sekarang belum diketahui secara pasti, begitu pula karir dan kehidupannya.

Menurut M. Plessner, Az-Zarnûjî hidup antara abad ke-12 dan ke-13. Dia adalah seorang ulama fiqh bermadzhab Hanafiyah, dan tinggal di wilayah Persia. Sedangkan Ahmad Fuad al-Ahwani memperkirakan bahwa Az-Zarnûjî wafat pada tahun $591 \mathrm{H} / 1195 \mathrm{M}$. Dengan demikian, belum diketahui hidupnya secara pasti, namun jika diambil jalan tengah dari berbagai pendapat di atas, az-Zarnuji wafat sekitar tahun 620-an H (Mahmud Yunus, 2008:169).

\section{Pendidikan Az-Zarnuji}

Mengenai riwayat pendidikannya bahwa Az-Zarnûjî menuntut ilmu di Bukhara dan Samarkand. Yaitu kota yang menjadi pusat kegiatan keilmuan, pengajaran dan lain-lainnya. Sedangkan guru-gurunya adalah Burhanuddiin Ali Bin Abu Bakar AlMarghinani, ulama besar bermazhab Hanafi yang mengarang kitab AlHidayah, Ruknul Islam Muhammad Bin Abu Bakarpopuler dengan Imaam Zadeh. Beliau ulama besar ahli fikih bermazhab Hanafi, pujangga sekaligus penyair, pernah menjadi mufti di Bukhoro dan sangat mashur fatwa193 Jurnal Al-hikmah Vol. 14, No. 2, Oktober 2017 
fatwanya. Wafat tahun 573H/1177 M. Ruknuddin al-Firginanî, seorang ahli fiqih, sastrawan dan penyair yang wafat tahun 594 H/ 1196 M; Hammâd bin Ibrâhim, seorang ahli ilmu kalam di samping sebagai sastrawan dan penyair, yang wafat tahun 594 H/ 1170 M. Syaikh Fakhrudi Al-Kasyani, pengarang kitab Bada-i 'us shana'i wafat tahun 587 H/1191 M. Syaikh Fakhrudin Qadli Khan Al Ouzjandi. Beliau wafat tahun $592 \mathrm{H} / 1196 \mathrm{M}$.

Dalam sejarah pendidikan kita mencatat, paling kurang ada lima tahap pertumbuhan dan perkembangan dalam bidang pendidikan Islam. Pertama pendidikan pada masa Nabi Muhammad saw. (571-632 M.), kedua pendidikan pada masa Khulafaur $\begin{array}{lll}\text { Rasyidin (632-661 } & \text { M.), ketiga }\end{array}$ pendidikan pada masa Bani Umayyah di Damsyik (661-750 M.), keempat pendidikan pada masa Kekuasaan Abbasiyah di Baghdad (750-1250 M.), dan kelima pendidikan pada masa jatuhnya kekuasaan khalifah di Baghdad (1250-sekarang) (Zuhairi,1992:7).

Jika melihat guru-guru Syaikh Zarnuji tersebut, dan dikaitkan dalam periodisasi di atas, bahwa Az-Zarnûjî hidup sekitar akhir abad ke-12 dan awal abad ke-13 (591-640 H./ 11951243 M.). Dari kurun waktu tersebut dapat diketahui bahwa Az-Zarnûjî hidup pada masa keempat dari periode pertumbuhan dan perkembangan pendidikan Islam sebagaimana disebutkan di atas, yaitu antara tahun 750-1250 M. Dalam catatan sejarah, periode ini merupakan zaman keemasan atau kejayaan Peradaban Islam pada umumnya, dan pendidikan Islam pada khususnya.

Pada masa tersebut, kebudayaan Islam berkembang dengan pesat yang ditandai oleh munculnya berbagai lembaga pendidikan, mulai dari tingkat dasar sampai pendidikan dengan tingkat perguruan tinggi. Di antara lembaga-lembaga tersebut adalah Madrasah Nižamiyah yang didirikan oleh Nizzam al-Muluk (457H./106M.), Madrasah al-Nuriyah al-Kubra yang didirikan oleh Nuruddin Mahmud Zanki pada tahun 563H./1234M. di Damaskus dengan cabangnya yang amat banyak di kota Damaskus, Madrasah alMustansiriyah Billah di Baghdad pada tahun 631 H./1234 M (Baharuddin \& Esa Nur Wahyuni , 2009: 51).

Kondisi pertumbuhan dan perkembangan tersebut di atas amat menguntungkan bagi pembentukan AzZarnûjî sebagai seorang ilmuan atau ulama yang luas pengetahuannya. Atas dasar ini tidak mengherankan jikaHasan Langgulung menilai bahwa Az-Zarnuju termasuk seorang filosof yang memiliki sistem pemikiran tersendiri dan dapat disejajarkan dengan tokoh-tokoh seperti Ibn Sina, Al-Ghazali, dan lain sebagainya (Abuddin Nata, 2003:106-107).

\section{Karya-Karya Az-Zarnuji}

Kitab Talîm al-Muta "allim, merupakan satu-satunya karya AzZarnûjî yang sampai sekarang masih ada. Sebagaimana pendapat Haji Khalifah dalam bukunya-Kasf al-Dzunûn ' an Asmâ' al-Kitâb al-Funûn, dikatakan bahwa Ta "lîm al- Muta "allim merupakan satu-satunya karya Imam az-Zarnûjî. Kitab ini telah diberi catatan komentar (Syarah) oleh Ibnu Ismâ'il.

Untuk lebih jelas dan lebih mengenal karya satu-satunya dari AzZarnuji ini, penulis akan memaparkan tentang kitab Ta'limul Muta'allim ini.

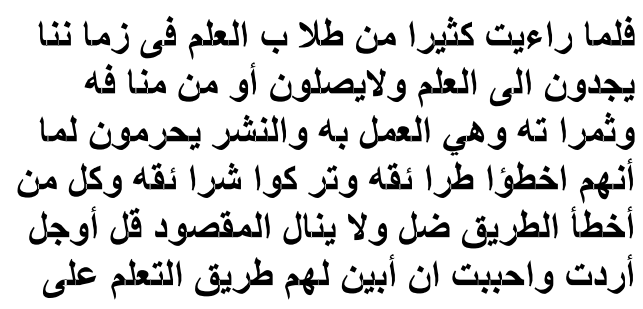

Oktober 2017 ISSN 1412-5382 


\section{مارايت في الكتب وسمعت من أسا تيذى أولى الدى}

Teks di atas pendahuluan dari kitab Ta'lim Al-Muta'allim, yang menjelaskan latar belakang penulisan kitab ini, kitab ini ditulis bermula dari kegundahan pengarangnya, Syaikh AzZarnuji, saat melihat banyaknya para pencari ilmu pada masanya yang gagal memperoleh apa yang mereka cari, sebagaimana yang beliau ungkapkan dalam pendahuluannya bahwa Banyak para pencari ilmu yang ternyata banyak di antara mereka yang mendapatkan ilmu, tetapi ternyata tidak bisa mendapatkan manfaat dan buahnya ilmu, yaitu dapat mengamalkan dan menyebarkan ilmu yang diperolehnyall. Menurut Syekh Az-Zarnûjî hal tersebut bisa terjadi, karena mereka salah jalan dalam mencari ilmu dan setiap orang yang salah jalan pastinya akan tersesat dan tidak sampai pada tujuannya. Mereka tidak tahu syarat-syarat yang harus dipenuhi dalam mencari ilmu sehingga mereka tidak mendapatkan ilmu pengetahuan sebagaimana diharapakan (Al- Jarnuzi :2).

Oleh karena itu kitab Ta "lîm alMuta "allim sebaiknya perlu kita kaji dan pelajari kembali oleh para penuntut ilmu dan para guru karena isinya masih relevan untuk pendidikan masa kini. Kitab yang beliau tulis bukan semata-mata hasil renungan spekulatif belaka, melainkan melalui penelitian terlebih dahulu terhadap para ulama sebelumnya yang dianggapnya telah berhasil yang banyak beliau kisahkan di dalamnya.

Penampilan materi kitab ini dikatakan baik, hal ini dapat dibuktikan dengan urutannya sebagai berikut: setelah basmalah, hamdalah dan shalawat secukupnya, kemudian menyebutkan judul kitab yang sesuai dengan isinya yang diabstraksikan sebelumnya. Sebelum itu pula dikemukakan alasan penyusunannya. Kemudian menampilkan keutamaan dan pengertian ilmu, hukum mempelajarinya sampai kepada bagaimana cara mengagungkan ilmu (Az-Zarnuji,tt:4).

\section{Adab Peserta Didik Dalam Pembelajaran}

Belajar sebagai sarana untuk memperoleh ilmu, haruslah melalui jalan dan persyaratan yang benar. Karena jalan yang benar dan persyaratan yang terpenuhi dalam belajar adalah kunci untuk mencapai keberhasilan belajar. Maka dari itu dalam kitab Ta "lîm al-Muta "allim Az-Zarnuji lebih memfokuskan pembahasannya pada jalan atau persyaratan (metode) yang harus ditempuh guna memperoleh keberhasilan belajar. Oleh karena itu sudah sepantasnya bagi para pencari ilmu harus mengetahui dan memahami syarat- syarat yang harus dipenuhi dalam mencari ilmu agar apa yang mereka harapkan bisa tercapai, yaitu mendapatkan ilmu yang bermanfaat dan bisa mengamalkannya.

Melihat kenyataan tersebut, terbesit dalam diri Az-Zarnûjî untuk menyusun sebuah kitab yang diberi nama Ta "lîm al-Muta "allim untuk membantu para pencari ilmu agar mereka mengetahui syarat-syarat yang harus mereka penuhi sebagai penuntut ilmu. Harapan dari penulis, kitab tersebut dapat membantu mengarahkan para penuntut ilmu melalui petunjukpetunjuk praktis, seperti bagaimana memilih ilmu, guru dan teman, waktuwaktu yang ideal untuk belajar, bagaimana metode belajar yang baik dan sebaginya.

Menurut Az-Zarnûjî adab belajar meliputi: Bagimana berniat dalam belajar, bagaimana memilih ilmu, guru, teman, dan ketabahan di dalam 
belajar, kemudian bagaimana penghormatan terhadap ilmu dan ulama, bagaimana keseriusan, ketekunan, dan minat dalam belajar, permulaan belajar, tata tertib belajar, tawakal dalam belajar, dan wara" dalam belajar. Itu semua adalah adab dan norma-norma serta tata urut belajar menurut Az-Zarnûjî yang dijelaskan dalam kitabnya Ta "lim al-Muta" allim. Adapun penjelasannya sebagai berikut:

\section{Niat saat belajar}

Menurut Az-Zarnûjî dalam kitab Ta "lîm-nya menyatakan bahwa belajar harus diniati untuk mencari ridha Allah, mengharap kebahagiaan di akhirat, menghilangkan kebodohan dari dirinya sendiri dan dari segenap orang-orang bodoh, menghidupkan agama dan melestarikan agama (AzZarnuji,tt:9).

Dan dalam menuntut ilmu hendaklah diniatkan juga untuk mensyukuri atas karunia akal dan kebugaran badan, hendaklah tidak diniati untuk mencari popularitas, tidak untuk kekayaan, juga tidak diniati untuk mencari jabatan dan semacamnya (AzZarnuji,tt:9).

Menurut Az-Zarnûjî̀, seyogyanya bagi para pencari ilmu harus berpikir dengan serius, supaya ilmu yang mereka cari tidaklah sia-sia. Jangan sampai ilmu yang ia peroleh digunakan untuk tujuan duniawi yang hina.

Dari pendapat beliau di atas, AzZarnûjî sangat mengecam bagi para penuntut ilmu yang hanya bertujuan untuk keduniawiaan belaka. Beliau lebih menekankan pada tujuan ukhrawi karena pada hakikatnya dunia adalah tempat singgah singgah sementara dalam perjalanan menuju akhirat.

Namun demikian, Az-Zarnûjî memperbolehkan mencari jabatan dengan pendidikannya dengan syarat hanya untuk menyeru kebaikan dan mencegah kemunkaran, menegakkan kebenaran dan mengagungkan agama bukan untuk kepentingan hawa nafsunya (Az-Zarnuji,tt:9).

\section{Memilih ilmu, guru, dan teman}

Memilih ilmu

Penuntut ilmu hendaklah memilih yang terbagus dari setiap bidang ilmu - ilmu yang terbagus adalah ilmu pengetahuan yang subtansi maupun illaborasinya jelas, tidak debatable dan tidak konroversial. Hal ini penting dinyatakan karena di sini kita sedang berbicara mengenai proses belajar atau Thuruqut Táallum-, memilih ilmu apa yang diperlukan dalam urusan agama di saat ini, kemudian apa yang diperlukan di waktu nanti. Dalam memilih ilmu (mentukan pilihan bidang studi/jurusan) para santri/siswa harus memilih ilmu/bidang studi yang paling baik atau paling cocok dengan dirinya (Az-Zarnuji,tt:23).

Suatu bidang ilmu yang dikaji akan sangat menarik dan menantang bagi mereka yang menyenanginya dan yang merasa cocok dengan bidang ilmu itu, sehingga motivasi berprestasi akan mendorongnya untuk tekun belajar, serta kedisiplinan yang tinggi dalam mengikuti seluruh proses belajar bahkan akan menjadi sumber kekuatan di manapun dan kapanpun, sehingga dalam konteks ini proses belajar tidak lagi mengenal tempat dan waktu.

Dalam kaitannya dengan memilih ilmu, Az-Zarnuji menganjurkan supaya mempelajari ilmu tauhid terlebih dahulu, kemudian ilmu-ilmu lama (karangan ulama salaf) dan menghindari ilmu-ilmu baru (Az-Zarnuji,tt:24).

\section{Memilih guru}

Diungkapkan Az-Zarnûî̂ bahwa: "Adapun dalam memilih guru, Jurnal Al-hikmah Vol. 14, No. 2, Oktober 2017 ISSN 1412-5382 
hendaknya memilih orang yang lebih alim (pandai), lebih wara "dan lebih tua." (Az-Zarnuji,tt:13). Az-Zarnûjî juga mengutip pendapat Abu Hanifah mengenai sifat-sifat tertentu yang harus dimiliki oleh guru, sebagai berikut:

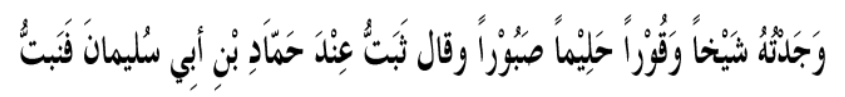

Ungkapan tersebut menunjukkan bahwa "alim, wara", dan lebih tua usianya dibanding muridnya, menurut Az-Zarnuji adalah syarat yang harus dipenuhi ketika menjadi guru. Dalam arti yang lebih luas lagi, kata tua dapat diartikan berarti orang yang banyak pengalamannya dalam segala hal maupun dalam menghadapi anak didik., sehingga lebih tepat apabila guru adalah orang yang lebih dewasa.

\section{Memilih teman}

Selain peran guru, peran lingkungan teman relasi juga tak kalah besaranya dalam membentuk karakter berpikir, pandangan hidup dan perilaku seorang pelajar.

Dalam kaitannya dengan hal ini menurut Az-Zarnuji sebaiknya memilih teman yang rajin belajar, bersifat wara' dan berwatak itiqamah (lurus) dan mudah paham (tanggap). Hindarilah orang yang malas, penganggur, pembual, suka berbuat onar dan suka memfitnah (Az-Zarnuji,tt:31).

\section{Menghormati ilmu, dan ahli ilmu}

Dalam melaksanakan pendidikan

Islam, peranan guru sangat penting sekali, artinya guru memiliki tanggung jawab untuk menentukan arah pendidikan tersebut. Itulah sebabnya Islam sangat menghargai dan menghormati orang-orang yang berilmu. Di antara menghormati ilmu, menurut Az-Zarnuji adalah sebagai berikut: "Di antara menghormati ilmu adalah memuliakan kitab, seorang pelajar (santri) sebaiknya tidak memegang kitab kecuali dalam keadaan suci dari hadas...hal ini disebabkan ilmu adalah cahay dan wudu juga cahaya. Dengan demikian cahaya ilmu tidak akan bertambah kecuali dengan berwudu." (Az-Zarnuji,tt:21).

$$
\text { Az-Zarnuji memberikan }
$$

kedudukan yang sangat tinggi terhadap guru. Dia harus dihormati dan dimuliakan. Kedudukan guru bagi muridnya tak ubahnya seperti orang tua terhadap anaknya, sebagaimana yang dikatakan oleh Al-jarnuzi:

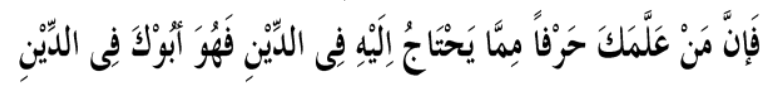

Az-Zarnuji memposisikan ahli ilmu (orang yang memiliki ilmu) terutama ahli fiqih jauh tingkatannya lebi tinggi dibandingkan dengan orang yang ahli ibadah. Beliau mengutip syair Muhammad bin Hasan bin Abdullah sebagai berikut:

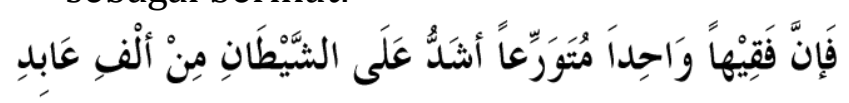

Artinya: "Sesungguhnya seorang ahli fiqih yang wara" (teguh) lebih berat bagi setan (untuk menggodanya) dibanding seribu 197 Jurnal Al-hikmah Vol. 14, No. 2, Oktober 2017 
ahli ibadah."

Az-Zarnuji menjelaskan tentang penghormatan terhadap guru dalam pasal tertentu, yaitu pasal ke empat tentang mengagungkan ilmu dan ahli ilmu. Yaitu sebagai berikut: (a) Memberikan sesuatu berupa hartanya atau apapun berupa sesuatu yang bermanfaat walaupun sedikit. Hal tersebut dilakukan agar anaknya bisa menjadi orang yang alim, jika anaknya tidak berhasil menjadi orang alim maka cucunya yang akan menjadi orang alim; (b) Tidak berjalan kencang di depannya; (c) Tidak duduk di tempat duduk gurunya; (d) Tidak memulai percakapan dengannya kecuali atas izinnya; (e) Tidak banyak bicara di hadapan guru; (f) Tidak menanyakan sesuatu ketika guru sedang bosan; (g) Menjaga waktu dan tidak mengetuk pintu atau kamarnya, tetapi harus menunggu sampai beliau keluar; (h)Menjauhi amarahnya dan menjalankan perintah yang baik darinya. Jika guru memerintahkan hal yang bertentangan dengan agama maka tidak boleh patuh kepadanya; dan (i) Menghormati anak-anaknya dan orang-orang yang memiliki hubungan kerabat dengannya (AzZarnuji: 37-40).

Menghormati guru adalah keharusan yang tidak dapat ditawar. Tanpa menghormati guru proses pendidikan berjalan tidak sesuai dengan koridornya. Proses pendidikan dianggap mengalami kegagalan Walau demikian guru bukanlah Tuhan yang harus sangat diagung-agungkan.

Kemudian termasuk dalam menghormati ilmu yaitu menghormati teman. Al-jarnuzi menjelaskan dalam kitabnya:
Artinya: "Termasuk memuliakan ilmu adalah menghormati teman dan orang yang memberikan pelajaran. Pertalian dan ketegantungan adalah sikap yang tercela kecuali dalam hal menuntut ilmu. Bahkan sebaiknya mengikat pertalian dan ketergantungan dengan guru dan teman-teman belajar". (AzZarnuji,tt:24).

\section{Keseriusan, ketekunan, dan cita-cita luhur}

Pelajar seyogyanya bersungguhsungguh hati dalam belajar serta tekun. Az-Zarnuji menukil ayat alquran berikut untuk memeperkuat pendapat :

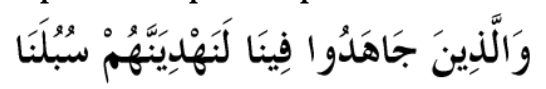

Artinya: "Dan orang-orang yang berjuang untuk (mencari keridhoan) kami,niscayakami akan berikan mereka kepada jalan-jalan kam.” (Q.S. AlAnkabut :29)

Selanjutnya

Az-Zarnuji mengarang syair yang isinya menceritakan kesungguhan para penuntut ilmu dalam memanfaatkan waktu belajar mereka. Mengenai keharusan untuk tekun dalam belajar Az-zarnuzi menjelaskan bahwa: "Adalah suatu keharusan bagi pelajar untuk tekun atau rutin dalam belajar serta mengulangi pada setiap awal dan akhir malam, karena antara waktu maghrib dan isya serta waktu sahur adalah waktu yang penuh berkah (Az-Zarnuji,tt:29).

Berkenaan dengan cita-cita luhur, Al-jarnuzi mencatat sebagai berikut : "Seorang penuntut ilmu harus memili cita-cita yang luhur dalam berilmu. Karena sesungguhnya seseorang akan terbang dengan cita-citanya sebagaimana burung tebang dengan sayapnya (Az-Zarnuji:55,57-58).

Baginya cita-cita tinggi tapi tidak Jurnal Al-hikmah Vol. 14, No. 2, Oktober 2017 ISSN 1412-5382 
ada kesungguhan berusaha, sungguhsungguh tetapi tidak ada cita-cita tinggi hanya akan memperoleh sedikit ilmu. Az-Zarnuji menandaskan pendapatya ini dengan syair gubahannya :

"Wahai jiwaku, tinggalkan kemalasan dan penundaan masalah, maka kau jatuhkan aku dalam kehinaan. Tak pernah kulihat sesuatu yang dapat diraih bagi pemalas kecuali penyesalan dan cita-cita yang tak terwujud." (Az-Zarnuji:61-62).

Karena itu, bagi Az-Zarnuji belum dianggap bersungguh-sungguh seorang penuntut ilmu melakukan aktifitas belajar, kalau belum mencapai kelelahan dan keletihan guna mencapai kesuksessan.

\section{Metode belajar}

Metode pembelajaran menjadi central position penting dalam setiap aktivitas pembelajaran. Penguasaan terhadap suatu materi yang dilakukan oleh seorang pendidik memang sangat dibutuhkan. Akan tetapi jauh lebih baik lagi jika materi yang dikuasai itu dapat disampaikan dengan metode pengajaran dalam pembelajaran. Karna metode merupakan sebuah sarana yang dapat memudahkan seorang pendidikan dalam menyampaikan pembelajaran. Dengan metode juga,pendidik dapat menjelaskan pembelajaran secara sistematis,efesien dan efektif. Melalui metode pembelajaran maka proses pembelajaran akan lebih mudah,serta peserta didik akan lebih cepat paham akan pembelajaran. Maka metode dalam pembelajaran sangatlah penting.

$$
\text { Az-Zarnûjî dalam Ta "lîm-nya }
$$
menawarkan kepada para pelajar untuk menggunakan metode-metode sebagai berikut: (1) Mengulang dan menghafal. Az-Zarnûjî menganjurkan agar selalu mengulang-ulang pelajaran yang telah diperolehnya, karena dengan cara mengulang-ulang maka akan mudah diingat dan dihafal; (2) Metode mużakarah. Metode mużakarah ini bisa dikatakan metode soal-jawab antara sesama pelajar atau bisa juga dikatakan tukar pendapat untuk saling melengkapi pengetahuan masingmasing. Hal ini dilakukan untuk membangkitkan ingatannya terhadap pelajaran-pelajaran yang sudah diterimanya; dan (3) Memahami dan mencatat. Az-Zarnûjî menganjurkan kepada para penuntut ilmu agar membuat ( $\mathrm{Ta}$ "liq pelajaran) catatan sendiri. Akan tetapi sebelum mencatat sebaiknya dipahami terlebih dahulu dan mengulanginya berkali-kali. Karena bila mencatat sesuatu yang belum dipahami akan membuat bosan, menghilangkan kecerdasan dan menyia-nyiakan waktu. Oleh karena itu anak didik harus bersungguh-sungguh memahami materi pelajaran lalu kemudian membuat catatan sendiri (Al-jarnuji:44).

Sebenarnya kolaborasi antara metode hafalan yang diberengi dengan aspek- aspek kognitif-rasional telah digariskan Az-Zarnuji dalam Kitab Ta'lim al- Muta'allim ini, hal ini tampak dalam kalimat

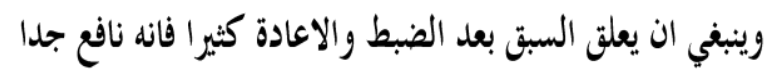

Artinya: "Sebaiknya siswa selalu mencatat sendiri mengenai pelajaran yang telah dihafalnya dan banyak mengulang karena sesungguhnya sangat bermanfaat ." (AzZarnuji:75).

\section{ولابد لطالب العلم من المذاكرة والمناظرة والمطارحة}

Artinya: "Seorang siswa hendaknya melakukan mudzakarah, munadharah, dan mutharahah." (Al-jarnuji, tt:79). 
Jelas bahwa ungkapan di atas mengisyaratkan bahwa di satu sisi AzZarnuji menganjurkan membuat catatan yang telah dihafal. Sementara itu, di sisi lain bagaimana mudzakarah (saling mengingatkan), munadharah (saling mengadu pandangan), dan mutharahah (diskusi) dijadikan sarana untuk mengembangkan aspek-aspek kognitifrasional dan pengembangan wawasan.

\section{Tawakkal}

Tawakal terambil dari kata Wakalyakilu yang berati "mewakilkan", dan dari kata ini terbentuk kata Wakil. Dalam beberapa ayat dijelaskan bahwa, "Dan Dia(Allah) atas segala sesuatu menjadi wakil (Q.S. Al-An'am: 102). dan cukuplah Allah sebagai wakil (AnNisa': 81). Kata wakil bisa juga diterjemahkan sebagai"pelindung" (AdDumaji,2006:8).

(1983) : "tawakkal adalah
menyerahkan keputusan
perkara, ikhtiar, dan usaha kapada
tuhan semesta alam".
para pelajar tentang tawakkal. Sebagaimana ia berkata: "Pelajar harus bertawakal dalam menuntut ilmu. Jangan goncang masalah rizki, hatinya pun jangan terbawa kesana." (Az-Zarnuji, tt: 53 ).

Pendapat Az-Zarnuji ini merupakan satu hal yang sangat benar, bahwa serang pelajar harus bertawakkal penuh terhadap Allah ketika sedang melaksanakan proses mencari ilmu atau hal-ha lain. Karena ketika seorang pelajar sudah berkurang rasa tawakkalnya maka lambat laun proses belajarnya pun akan terganggu. Akan tetapi, tidak dapat dipungkiri bahwa masalah yang sering mendera seorang pelajar adalah masalah rizqi (keuangan).

Az-Zarnuji megingatkan pengaruh urusan dunia dengan penjelasanya sebagai berikut:

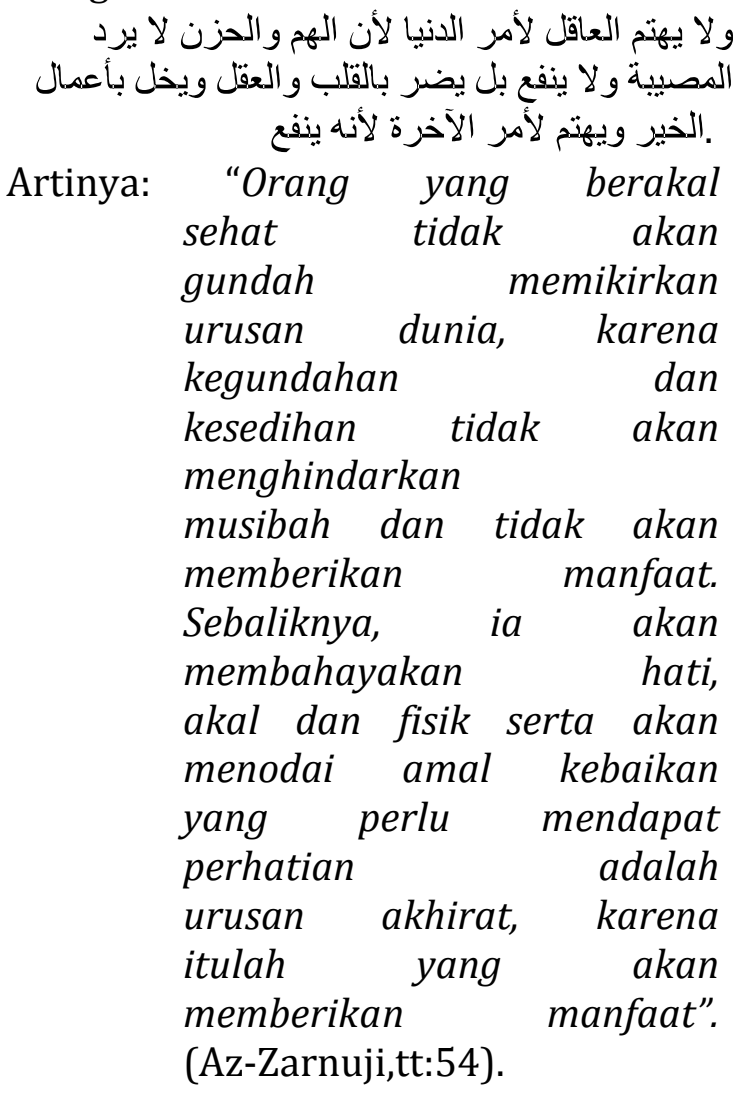

Dalam komentarnya ini Az-Zarnuji memberikan peringatan kepada para pelajar khususnya dan kalangan umum pada umumnya. Ada beberapa hal yang dapat kita ambil dari komentarnya ini, yaitu: (1) jangan terlalu memikirkan urusan dunia karna ia akan mengkotori hati; (2) Dunia akan melalaikan dirimu ketika mencintai dunia; dan (3) Perbanyaklah amal akhirat karna kita akan kembali dan itulah negeri yang abadi.

\section{Wara'}

Selanjutnya menurut Az-Zarnuji, seorang pelajar harus bersifat wara' (Self Protection) dalam mencari ilmu. secara harfiah kata wara" berarti -menjauhkan diri dari dosa, maksiat dan perkara syubhat. Ulama membagi wara' $^{\prime}$ menjadi tiga macam. Pertama, wara'

Jurnal Al-hikmah Vol. 14, No. 2, Oktober 2017 ISSN 1412-5382 
wajib, yaitu: mencegah diri dari perbuatan haram, dan ini wajib dilaksanakan oleh setiap orang. Kedua, Wara Mandub (sunnah), yaitu: mencegah diri dari perkara-perkara syubhat, dan ini biasanya dilakukan oleh sebagian kecil orang. Ketiga, Wara' dari Mubahat (Perbuatan yang boleh dilakukan) yang tidak penting, dan ini sifat dan karakter pribadi para nabi, syuhada dan orang- orang shaleh (afrizal, 2008:187 ).

Az-Zarnuji berpendapat bawha termasuk berbuat waro' adalah memelihara dirinya jangan sampai perutnya kenyang amat, terlalu banyak tidur dan banyak membicarakan hal yang tak bermanfaat (Az-Zarnuji,tt:66).

Di antara tanda yang mendasar bagi orang-orang yang wara" adalah kehati- hatian mereka yang luar biasa dari sesuatu yang haram dan tidak adanya keberanian mereka untuk maju kepada sesuatu yang bisa membawa kepada yang haram. Dan dalam hal itu, Rasulullah saw bersabda, yang artinya: "Menceritakan kepada kami Muhammad bin Katsir: Mengkhabarkan kepada kami Sufyan dari Abi Farwah dari Sya "bi dari $\mathrm{Nu}$ "man bin Basyir berkata: Rasulullah Saw. Bersabda: (perkara) yang halal itu jelas dan (perkara) yang haram juga jelas. Sementara itu, (perkara yang ada) di antara keduanya adalah perkaraperkara syubhat (yang samar) yang tidak diketahui oleh bagian besar manusia. Barang siapa yang menhindari (semua perkara) syubhat, maka dia telah menjaga kesucian agama dan dirinya. Namun, barang siap yang terjerumus ke dalam (perkara) syubhat, maka dia telah terjerumus ke dalam perkara yang haram." (HR. Bukhari dan Muslim)

Hadis di atas menjelaskan bahwa yang halal dan yang haram itu sudah jelas dan yang berada di antaranya itu adalah perkara syubhat. Orang yang hatinya bersih dan takut terhadap Allah, dia akan meninggalkan hal-hal yang berada di antara halal dan haram (perkara syubhat), karena bila terjerumus ke dalam perkara yang syubhat (samar-samar hukumnya) maka akan terjerumus ke dalam perkara yang haram pula.

Sifat wara' adalah sesuatu yang berkenaan dengan hati. Maka sifat wara' ini bisa tertanam dalam diri apabila sudah sepenuhnya bisa meniggalkan perkara-perkara yang haram apalagi sesuatu yang syubhat yang tidak jelas setatus hukumnya dan selalu berupaya untuk memperbaiki diri dengan bertaubat kepada Allah di samping kehati-hatian.

\section{Implikasi Pemikiran Az-Zarnuji Tentang Adab Peserta Didik Dalam Pembelajaran Terhadap Pendidikan Karakter Di Indonesia}

Adab merupakan kebiasan yang dimiliki oleh sesorang yang di implementasikan dalam bentuk perbuatan, yang akan melahirkan akhlak. Adab dibutuhkan dalam kehidupan, terutama bagi peserta didik, dengan tujuan agar siswa tumbuh menjadi pribadi yang baik.

\section{Implikasi niat saat belajar}

Az-Zarnuji menyatakan bahwa belajar harus diniati untuk mencari ridha Allah, mengharap kebahagiaan di akhirat, menghilangkan kebodohan dari dirinya sendiri dari segenap orang-orang bodoh, menghidupkan agama dan melestarikan agama juga untuk mensyukuri atas karunia akal dan kebugaran badan, hendaklah tidak diniati untuk mencari popularitas, tidak untuk kekayaan, juga tidak diniati untuk mencari jabatan dan semacamnya (AzZarnuji,tt:9).

Maka implikasi dari niat belajar terhadap karakter seeorang adalah 
tumbuhnya sikap religius dalam dirinya.

\section{Implikasi dari memilih ilmu, guru, dan teman.}

Az-Zarnuji menganjurkan kepada para pelajar hendaklah memilih yang terbagus dari setiap bidang ilmu - ilmu yang terbagus yaitu ilmu pengetahuan yang subtansi maupun illaborasinya jelas, tidak debatable dan tidak konroversial. Dalam hal memilih guru Az-Zarnuji menyarankan agar memilih yang lebih alim, lebih tua, dan bersifat wara'. Dan dalam kaitannya dengan memilih teman Az-Zarnuji menyarankan agar memilih teman yang rajin belajar, bersifat wara' dan berwatak istiqamah (lurus) dan mudah paham (tanggap) serta hindari orang yang malas, penganggur, pembual, suka berbuat onar dan suka memfitnah (Aljarnuzi,tt:13).

Maka ketika seorang dalam pembelejaran pandai dalam memilih ilmu,guru, dan teman terwujudlah dalam dirinya karakter jujur, bersahabat/ komunikatif, cinta damai, serta peduli sosial.

\section{Implikasi menghormati ilmu dan ahli ilmu}

Az-Zarnuji berkata: Di antara menghormati ilmu adalah memuliakan kitab, seorang pelajar (santri) sebaiknya tidak memegang kitab kecuali dalam keadaan suci dari hadas.hal ini disebabkan ilmu adalah cahaya dan wudu juga cahaya. Dengan demikian cahaya ilmu tidak akan bertambah kecuali dengan berwudu'. Az-Zarnuji memberikan kedudukan yang sangat tinggi terhadap guru. Dia harus dihormati dan dimuliakan. Kedudukan guru bagi muridnya tak ubahnya seperti orang tua terhadap anaknya (Az-
Zarnuji,tt:20).Dari sini maka tumbuhlah karakter tanggung jawab.

\section{Implikasi keriusan, ketekunan, dan cita-cita luhur}

Dalam hal ini Az-Zarnuji berkata: keharusan bagi pelajar untuk tekun atau rutin dalam belajar serta mengulangi pada setiap awal dan akhir malam, karena antara waktu maghrib dan isya serta waktu sahur adalah waktu yang penuh berkah. seorang penuntut ilmu harus memili cita-cita yang luhur dalam berilmu. Karena sesungguhnya seseorang akan terbang dengan citacitanya sebagaimana burung tebang dengan sayapnya (Az-Zarnuji:55,57-58).

Apabila dalam diri seorang memiliki sifat tekun dan serius dalam pembelajaran maka akan tumbuh dalam dirinya karakter tanggung jawab,dan kerja keras.

\section{Implikasi Metode belajar}

Metode pembelajaran menjadi central position penting dalam setiap aktivitas pembelajaran. Dalam hal metode belajar Az-Zarnuji lebih menekankan terhadap menghafal. Sementara itu, di sisi lain bagaimana mudzakarah (saling mengingatkan), munadharah (saling mengadu pandangan), dan mutharahah (diskusi) dijadikan sarana untuk mengembangkan aspek-aspek kognitif-rasional dan pengembangan wawasan (AzZarnuji,tt:44).

Karakter yang tumbuh dari metode menghafal ini adalah Menghargai perestasi Gemar membaca, dan juga akan tumbuh karakter kerja keras.

\section{Implikasi tawakkal}

Az-Zarnuji berpesan kepda setiap pelajar harus bertawakal dalam menuntut ilmu. Jangan goncang 2, Oktober 2017 ISSN 1412-5382 
masalah rizki, hatinya pun jangan terbawa kesana. Dia harus yakin bahwa Allah akan menolongnya, karna dia berada dalam hal menolong agama (AzZarnuji,tt:53). Karna tawakkal adalah menyerahkan keputusan segala perkara, ikhtiar, dan usaha kapada tuhan semesta alam.

Ketika telah ada dalam diri seorang yang namanya sifat tawakkal maka secara tidak langsung akan tumbuhlah karakter religius, dan jujur.

\section{Implikasi wara'}

Selanjutnya menurut Az-Zarnuji, seorang pelajar harus bersifat wara' (Self Protection). Termasuk berbuat waro' adalah memelihara dirinya jangan sampai perutnya kenyang amat, terlalu banyak tidur dan banyak membicarakan hal yang tak bermanfaat (AzZarnuji,tt:64).

Kata wara" berarti -menjauhkan diri dari dosa, maksiat dan perkara syubhat. Maka dari sifat wara' ini akan memunjulkan yang namanya karakter religius, cinta damai, peduli lingkungan, peduli sosial, jujur, tanggung jawab dan bersahabat. Dapat kita simpulkan mendasar dari pengertian wara' yang dimaknai dengan menjauhkan diri dari dosa, maksiat dan perkara syubhat maka jelaslah akan tumbuh karakter yang telah disebutkan diatas.

\section{PEMBAHASAN}

\section{Adab peserta didik dalam belajar}

Al-Jarnuzi adalah merupakan ahli didik islam yang sangat memperhatikan bagaimana agar peserta didik berhasil dalam belajar. ia lebih menekankan terhadap metode, ataupun cara dalam hal memperoleh ilmu. Maka yang pertama sekali yang anjurkan oleh AzZarnuji dalam proses pembelajaran adalah niat. Pada hakikatnya niat juga merupakan tujuan yang ingin dicapai. Ini sesuai dengan hadits Rasulullah Saw, yang berbunyi:

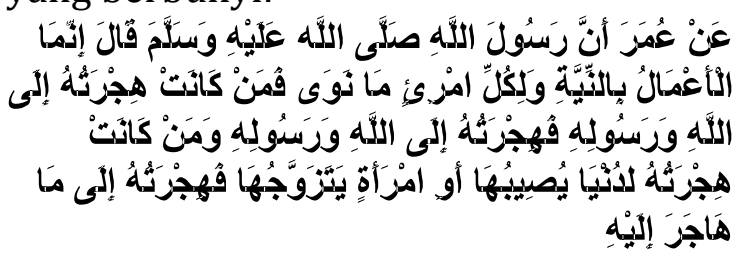

Artinya: "Dari Umar radhiyallahu 'anhu, bahwa Rasulullah shallallahu 'alaihi wa sallam bersabda, "Amal itu tergantung niatnya, dan seseorang hanya mendapatkan sesuai niatnya. Barang siapa yang hijrahnya kepada Allah dan Rasul-Nya, maka hijrahnya kepada Allah dan Rasul-Nya, dan barang siapa yang hijrahnya karena dunia atau karena wanita yang hendak dinikahinya, maka hijrahnya itu sesuai ke mana ia hijrah." (HR. Bukhari, Muslim, dan empat imam Ahli Hadits) (hadits. Bukhari no. 1 dan Muslim no. 1907).

Niat adalah tolok ukur suatu amalan; diterima atau tidaknya tergantung niat dan banyaknya pahala yang didapat atau sedikit pun tergantung niat. Niat merupakan perkara hati yang urusannya sangat penting. Niat juga adala keinginan seseorang untuk mengerjakan sesuatu, tempatnya di hati bukan di lisan. Maka niat dalam semua aspek pekerjaan adalah prioritas utama. Karena hasil dari apa yang kita perbuat adalah cerminan dari baik atau tidaknya niat.

Disaat peroses pembelajaran menurut Az-Zarnuji pengaruh dari pada guru, dan teman sangat mempengaruhi terhadap pencapaian tujuan pendidikan itu sendiri. Karna guru adalah central pada saat pembelajaran berlangsun, maka perannya sangat penting.

Dalam paradigma jawa, guru diidentikkan dengan guru ( $g u$ dan ru) yang berarti "digugu dan ditiru". 
Dikatakan digugu (dipercayai) karna guru memiliki seperangkat ilmu, wawasan, dan pandangan yang luas dalam melihat kehidupan. Dikatakan ditiru (diikuti) karena guru memiliki kepribadian yang utuh, yang karenanya segala tindak tanduknya patut dijadikan panutan dan suri tauladan oleh muridnya (Abdul Mujib, Jusuf Muzakkir, 2010:9).

Terkait hormat terhadap guru pada saat ini konsep Az-Zarnuji masih relevan, akan tetapi mengingat seiring berkembangnya budaya yang bercampur pada budaya barat, maka makna menghormati itu berubah yang dulunya klasik menjadi modern, yang dulunya ketika siswa bertemu guru itu tunduk (patuh), dan ketika dalam pembelajaran siswa hanya menerima pelajaran tanpa bertanya kecuali ditawarkan pertanyaan yang kesemua itu berubah menjadi ketika siswa bertemu guru itu saling menyapa, kemudian dihampiri dan terjadilah percakapan antara guru dan murid layaknya teman dekat dan dalam pembelajaran siswapun bertanya ketika tidak mengerti tanpa ada penawaran dari guru. Hal itu semua menurut konteks pemahaman saya masih dalam batas menghormati. Jadi tergantung kita memaknai konteks pada masa sekarang.

Didalam ungkapannya juga AzZarnuji mengatakan bahwa seorang murid tidak boleh bertanya kecuali setelah diperbolehkan dan hendak memilih guru yang wara', lebih tua dan alim. Mungkin hal ini dalam pendidikan formal sangat sulit dalam penerapannya. Karna disekolah tersebut sudah ditentukan guru-gurunya. Kita tidak bisa memilih guru mana yang masuk kategori wara' dan alim. Dan pendidikan sekarang lebih mengarah kepada studan center bukan guru center lagi. Maka sepatutnya lah para peserta didik lebih banyak bertanya agar lebih mengerti dalam pembelajaran.
Di dalam berteman pandailah dalam memilihnya. Jangan sampai ia sibuk karnanya yang dapat membuangbuang waktu. Hendaklah berkawan dengan orang-orang yang rajin dalam belajar, yang dapat hendaknya menasehati dan mengingatkan ketikat salah dalam berbuat.

Pelajar seyogyanya bersungguhsungguh hati dalam belajar serta tekun. Rasullulah Saw pernah bersabda:

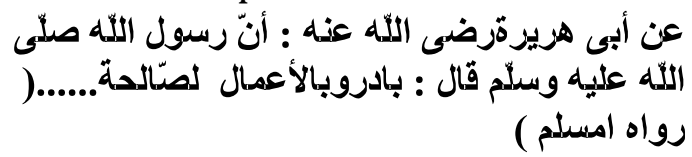

Artinya: "Dari Abu Hurairah ra. ia berkata : "Sesungguhnya Rasulullah saw. bersabda : "Bersegeralah kalian untuk mengerjakan amal-amal saleh." (H.R.Muslim).

Serta dalam belajar juga harus menanamkan cita-cita. Karena dengan menanamkan cita-cita, maka seseorang akan berusaha sekuat mungkin untuk meraih, mencapai dan mendapatkannya. Seperti contah orang yang mempunyai cita-cita mendaki gunung, maka ia akan berusaha agar sampai dipunjaknya. Begitulah seharusnya pelajar takkan berhenti sebelum mendapatkan apa yang dia cita-citakan.

Dalam metode belajar, Az-Zarnuji lebih menekankan pendidikan pada hafalan. Mungkin banyak kalangan yang mengkritisinya, terutama pada era moderen ini. Permasalahannya adalah apakah betul pembelajaran yang menggunakan teknik menghafal menjadikan anak didik yang kurang kreatif, tidak mampu mengembangkan pengetahuan yang dimiliki, dan ada dalam kadar keaktifan mental yang paling rendah sebagaimana dituduhkan.

Hal itu mungkin benar jika dalam proses pembelajaran hanya dipraktekan metode hafalan saja tanpa dibarengi dengan aspek-aspek kognitif-rasional dan pengembangan wawasan, seperti yang sering dijumpai dalam proses 2, Oktober 2017 ISSN 1412-5382 
pengajaran kitab kuning di banyak pesantren. Namun, jika yang terjadi adalah mengkolaborasikan antara keduanya, yaitu metode hafalan yang diberengi dengan aspek-aspek kognitifrasional, hal ini dapat dikatakan suatu keberhasilan dalam proses pendidikan, karena pada dasarnya hafalan akan memperkuat argumen dalam suatu keilmuan.

Az-Zarnuji juga menganjurkan membuat catatan yang telah dihafal. Sementara itu, di sisi lain bagaimana mudzakarah (saling mengingatkan), munadharah (saling mengadu pandangan), dan mutharahah (diskusi) dijadikan sarana untuk mengembangkan aspek-aspek kognitif-rasional dan pengembangan wawasan. Dalam poin ini Az-Zarnûjî menyarankan beberapa metode dalam hal belajar menurut pandangannya. Dalam pendidikan era modern ini ada sebagian pendapat AzZarnûjî yang dipakai yaitu metode diskusi, sebagai sarana pengembangan cara berpikir seorang pencari ilmu.

Akan tetapi yang sangat disayangkan adalah berkurangnya daya ingat pencari ilmu karena kurangnya kebiasaan menghafal. Sebagaimana yang telah dikatakan Az-Zarnûjî, metode menghafal di era modern ini dianggap metode yang mengurangi kreatifitas seorang pencari ilmu. Menurut penulis, padahal jika dibiasakan menghafal maka kemampuan daya ingat akan semakin meningkat. Jika Az-Zarnûjî mengutamakan memahami dibanding mencatat, maka penulis berbeda pandangan dengan beliau. Dalam hal ini bukan berarti penulis menyalahkan beliau, akan tetapi lebih melihat kepada kondisi daya tangkap para pencari ilmu dimasa sekarang ini.

Juga dalam belajar, seorang pelajar didik janga lupa menyerahkan segala urusannya kepada Allah Swt. Karna hanya Allahlah yang bisa memberikan maafaat dan memberikan mudrat.dalam artian kata seorang pelajar haruslah bertawakkal kepada Allah Swt.

Tak kalah pentingnya seorang pelajar harus bersifat wara' (Self Protection) dalam mencari ilmu. Wara' ini merupakan sifat yang mampu memlihara diri dari perkara-perkara yang haram dan syubhat. Dengan menanamkannya maka pelajar akan memiliki hati yang bersih dan akan memudahkan ilmu masuk kedalam hatinya.

\section{Implikasi Adab Peserta Didik terhadap Pendidikan Karakter}

Maka implikasi dari niat belajar terhadap karakter seeorang adalah tumbuhnya sikap religius dalam dirinya. Ini bisa kita pahami dari makna religius yaitu sikap dan perilaku yang patuh dalam melaksanakan ajaran agama yang dianutnya. Dapat disimpulkan bahwa orang yang berniat saat belajar, maka telah tertanam dalam dirinya karakter religius.

Ketika seorang dalam pembelejaran pandai dalam memilih ilmu,guru, dan teman terwujudlah dalam dirinya karakter jujur, bersahabat/ komunikatif, cinta damai, serta peduli sosial. Karena jujur adalah perilaku yang didasarkan pada upaya menjadikan dirinya sebagai orang yang selalu dapat dipercaya dalam perkataan, tindakan, dan pekerjaan. Sedangkan karakter bersahabat adalah tindakan yang memperlihatkan rasa senang berbicara, bergaul, dan bekerja sama dengan orang lain. Juga cinta damai adalah sikap, perkataan, dan tindakan yang menyebabkan orang lain merasa senang dan aman atas kehadiran dirinya. Serta peduli social adalah sikap dan tindakan yang selalu ingin memberi bantuan pada orang lain dan masyarakat yang membutuhkan Jelaslah sudah bahwa dengan mengamalkan konsep AzZarnuji mengenai memilih ilmu, guru, 
dan teman maka tumbuhlah karakter jujur, bersahabat, cinta damai, serta peduli sosial.

Dari adab menghormati ilmu dan ahli ilmu maka tumbuhlah karakter tanggung jawab. Karna Tanggung jawab adalah Sikap dan perilaku seseorang untuk melaksanakan tugas dan kewajibannya, yang seharusnya dilakukan terhadap diri sendiri, masyarakat, lingkungan, (alam, sosial, dan budaya), negara, dan tuhan yang maha esa. Dari sini juga akan tumbuh karakter Demokratis yaitu: cara berpikir, bersikap, dan bertindak yang menilai sama hak dan kewajiban dirinya dan orang lain.

Apabila dalam diri seorang memiliki adab tekun dan serius dalam pembelajaran maka akan tumbuh dalam dirinya karakter tanggung jawab,dan kerja keras. Bahwasanya kerja keras adalah perilaku yang menunjukkan upaya sungguh-sungguh dalam mengatasi berbagai hambatan belajar dan tugas, serta menyelesaikan tugas dengan sebaik-baiknya. Apabila sudah kerja keras berarti dia tekun dan serius dalam belajar. Dan orang yang mempunyai sebuah cita-cita juga akan bekerja keras sekuat tenaga untuk mendapatkan apa yang ia cita-citakan.

Karakter yang tumbuh dari metode menghafal ini adalah Menghargai perestasi yaitu: sikap dan tindakan yang mendorong dirinya untuk menghasilkan sesuatu yang berguna bagi masyarakat. Dibalik itu juga akan tumbuh karakter Gemar membaca yaitu: kebiasaan menyediaakan waktu untuk membaca berbagai bacaan yang memberikan kebajikan bagi dirinya. Juga karakter kerja keras.

Ketika telah ada dalam diri seorang yang namanya sifat tawakkal maka secara tidak langsung akan tumbuhlah karakter religius, dan jujur. Karna religius sikap dan perilaku yang patuh dalam melaksanakan ajaran agama. Sedangkan jujur perilaku yang didasarkan pada upaya menjadikan dirinya sebagai orang yang selalu dapat dipercaya. Maka karakter yang dunia ini mempunyai keterkaitan antar satu dengan yang lain. ketika telah tertanam sikap tawakkal dalam belajar akan tertanam juga lah karakter religius dan jujur.

Maka dari sifat wara' ini akan memunjulkan yang namanya karakter religius, cinta damai, peduli lingkungan, peduli sosial, jujur, tanggung jawab dan bersahabat. Dapat kita simpulkan mendasar dari pengertian wara' yang dimaknai dengan menjauhkan diri dari dosa, maksiat dan perkara syubhat maka jelaslah akan tumbuh karakter yang telah disebutkan diatas.

\section{SIMPULAN}

Dari rangkaian pembahasan dan beberapa uraian di atas, maka adab belajar siswa dan implikasinya terhadap pendidikan karakter dalam penelitian ini dapat disimpulkan bahwa adab belajar menurut Az-Zarnuji merupakan kumpulan sikap dan perilaku yang harus dijalani oleh para pelajar dalam menjalani proses pembelajaran. Dari hasil penelitian menyimpulkan bahwa akhlak belajar atau etika yang harus dimiliki oleh para pelajar Islam adalah: pertama, niat saat belajar, kedua,memilih guru ketiga, menghormati guru, keempat, keseriusan ketekunan dan cita-cita luhur, kelima metode belajar, keenam tawakal dan ketujuh wara

Impikasi pendidikan karakter terhadap adab peserta didik dalam belajar dalam konsep Az-Zarnuji maka yang tumbuh dari niat adalah karakter religius, dari memilih ilmu, guru, dan teman terwujudlah dalam dirinya karakter jujur, bersahabat/ komunikatif, cinta damai, serta peduli sosial, dari adab menghormati ilmu dan

Jurnal Al-hikmah Vol. 14, No. 2, Oktober 2017 ISSN 1412-5382 
ahli ilmu maka tumbuhlah karakter tanggung jawab dan demokratis, dari adab tekun dan serius dalam pembelajaran maka akan tumbuh dalam dirinya karakter tanggung jawab dan kerja keras, dari metode ini akan tumbuh karakter menghargai perestasi, gemar membaca dan kerja keras, dari sifat tawakkal maka secara tidak langsung akan tumbuhlah karakter religius, dan jujur, dari sifat wara' ini akan memunjulkan yang namanya karakter religius, cinta damai, peduli lingkungan, peduli sosial, jujur, tanggung jawab dan bersahabat.

\section{DAFTAR RUJUKAN}

Haris, Abd., 2010. Etika Hamka. Yokyakarta: PT. Lkis printing cemerlang.

Nada, Abdul A'ziz bin Fathi As-Sayyid. 2007. Ensiklopedia Islam menurut Al-Qur'an dan As-Sunnah. Jakarta: Pustaka Imam Asy-Syafi'i.

Majid, Abdul \& Andayani, Dian. 2011. Pendidikan Karakter Persepektif Islam. Bandung:PT. Remaja Rosdakarya.

Ulwan, Abdullah Nasih. 2002. Pedoman Pendidikan Anak Dalam Islam. Jakarta.

Nata, Abuddin. 2013. Aklah Tasawuf Dan Karakter Mulia. Jakarta: PT. Raja Grafindo Persada. 2000. Pemikiran Para Tokoh Pendidikan Islam. Jakarta: Raja Grafindo.

2012. Pemikiran Pendidikan Islam Dan Barat. Jakarta: PT. Raja Grapindo Persada.

Wibowo, Agus. 2013. Manajemen Pendidikan Karakter Disekolah. Yogyakarta: Pustaka pelajar.

Al-Ghazali. 2007. Ihya Ulumddin, cet-ke 2. Jakarta: Pustaka Amani.
Al-jumbulati, Ali \& At-twainisi, Abdul Futuh. Perbandingan Pendidikan Islam. Jakarta: Rineka Cipta.

M., Amril. 2005. Etika Dan Pendidikan. Yogyakarta: Aditya Media.

Wiyani, Ardy \& Barnawi. 2012. Ilmu Pendidikan Islam. Jogjakarta: ArRuzz Media.

Az-Zarnuji. tt. Ta'limul mutaa'llim. Surabaya: Nurul Hadi.

Baharuddin dan Wahyuni, Esa Nur. 2009. Teori Belajar dan Pembelajaran. Jogjakarta: Ar- Ruzz Media.

Salam, Burhanuddin. 2000. Etika Sosial (Asas Moral Dalam Kehidupan Manusia). Jakarta: PT Rineka Cipta.

Departemen Agama Repblik Indonesia. 1997. Al-Qur'an dan Terjemahannya. Semarang: CV. Toha Putra.

Dimyati \& Mujiona. 2009. Belajar Dan Pembelajaran. Jakarta: Rineka Cipta.

Mulyasa, E., 2011. Manajemen Pendidikan Karakter. Jakarta: PT. Bumi Aksara.

Elfindri, Lilik Hendrajaya, dkk., 2012. Pendidikan Karakter Kerangka, Metode, dan Aplikasi Untuk Pendikan Pendidikan dan Profesional. Jakarta: Baduose Madia.

Arifin, H.M., 2011. Ilmu Pendidikan Islam: Tinjauan Teoretis dan Praktis Berdasarkan Pendekatan Interdisipliner. Jakarta: Bumi Aksara.

Hamka. 1983 . Tasawuf Modern. Jakarta: Panjimas.

Isjoni \& Firdaus. 2008. Pembelajaran Terkini. Yogyakarta: Pustaka Belajar.

Moleong, Lexy J., 2000. Metode Penelitian Kualitatif. Bandung: PT. Remaja Rosdakarya.

Yunus, Mahmud. 2008. Sejarah Pendidikan Islam. Jakarta: Mahmud Yunus Wadzurriyah. 
Muhaimin, Abdul Mujib dan Mudzakkir, Jusuf. 2012. Studi Islam Dalam Rangka Dimensi Dan Pendekatan. Jakarta: Kencana Prenada Media Group.

Al-kaysi, Marwan Irahim. 2003. Petunjuk Praktis Akhlak Islam. Jakarta: Lentera Basritama.

Muslich, Masnur. 2011. Pendidikan Karakter Menjawab Tantangan Krisis Multidimensional. Jakarta: PT. Bumi Aksara.

Muztaba, Skripsi Uin Syarif Hidayatullah, Jakarta: 2014.

Muhadjir, Noeng. 1989. Metodologi Penelitian Kualitatif, Tela'ah Positivistik, Rasionalistik Fenomenologi, Realisme Methophisik. Yogyakarta: Rakeb Sarasin.

Nizar, Samsul. 2011. Sejarah Pendidikan Islam. Jakarta: Kencana Prenada Media Group. 2008. Memperbincangkan Dinamika Intelektual Dan Pemikiran Hamkatentang Pendidikan Islam. Jakarta: Kencana Prenada Media Group.
Sugiono. 2013. Metode Penelitian Kuantitatif, Kualitatif Dan R\&D. Bandung: Alfabeta.

Sukardi. 2007. Metodologi Penelitian Pendidikan: Kompetensi dan Prakteknya. Jakarta: Bumi Aksara.

Sagala, Syaiful. 2013. Konsep Dan Makna Pembelajaran, Bandung: Cv. Alfabeta,

Andrianto, Tuhana Taufik. 2011. Mengembangkan Karakter Sukses Anak Diera Cyber. Jokjakarta: ArRuzz Media.

Ad-Dumaiji, Umar. 2006. At-Tawakkal Alallah Ta'la. Jakarta: PT. Darul Falah.

Umiarso \& Makmur, Haris Fathoni. 2010. Pendidikan Islam Dan Krisis Moralisme Masyarakat Modern. Jogjakarta: Ircis0d.

Aqib, Zainal. 2009. Menjadi Guru Propesional Berstandar Nasional, Bandung: Yramawidya.

Zubaidi. 2013. Desain Pendidikan Karakter. Jakarta: Kencana Prenada Media Group.

Ali, Zainuddin. 2011. Pendidikan Agama Islam. Jakarta: Bumi Aksara.

Zuharini. 1992. Sejarah Pendidikan Islam. Jakarta: Bumi Aksara. 